\title{
MARTÍN DE GAMECHO, UN MAESTRO CANTERO VIZCAÍNO AL SERVICIO DE LA NOBLEZA MENDOCINA (1503-1521)
}

\author{
Raúl Romero Medina* \\ Universidad de Cádiz
}

\section{RESUMEN}

El presente estudio indaga en la figura de un maestro cantero vizcaíno, Martín de Gamecho. Gracias a la documentación conservada en los archivos nobiliaros, podemos acercarnos, en parte, a su trayectoria profesional, la cual se desarrolla en Castilla durante la primera mitad del siglo XVI. De hecho, estuvo vinculado con la ejecución de obras patrocinadas por algunos miembros de la familia Mendoza, como la Casa Ducal de Medinaceli o la Casa Ducal del Infantado, siendo el responsable de algunos de los trabajos de cantería en la Iglesia de Santa María de Medinaceli -Soria- y en el Palacioalcázar de Buitrago del Lozoya -Madrid-.

Palabras Claves: Maestro cantero, Martín de Gamecho, Castilla, siglo XVI, Casa Ducal de Medinaceli, Casa Ducal del Infantado.

\section{ABSTRACT}

This study sheds some light upon stonemason master from Biscay Martin de Gamecho. The files preserved in certain noble archives help us approach his professional trajectory to some extent, which was developed in Castile during the first half of the 16th century. As a matter of fact, he was in charge of some constructions with funds provided by certain members of the Mendoza family such as the Casa Ducal de Medinaceli or the Casa Ducal del Infantado. He was actually responsible for part of the stonework at the Santa Maria de Medinaceli church in Soria, and the Buitrago del Lozoya Palacecitadel in Madrid.

Key words: stonemason master, Martín de Gamecho, Castile, 16th century, Casa Ducal de Medinaceli (Ducal House of Medinaceli), Casa Ducal del Infantado (Ducal House of the Infantado).

\footnotetext{
Investigador Contratado del Área de Historia del Arte. Facultad de Filosofía y Letras. Departamento de Historia Moderna, Contemporánea, de América y del Arte. Universidad de Cádiz. raul.romero@uca.es.
} 


\section{Introducción ***}

En el alborear del gobierno de los Reyes Católicos, Castilla vive inmersa en una gran fiebre constructiva. La propia Corona, secundada por las altas esferas eclesiásticas y la nobleza castellana, favoreció la llegada del "gusto" tardogótico, el cual se hizo posible gracias a la importación de arquitectos noreuropeos quienes, a través de los principales talleres catedralicios ${ }^{1}$, no sólo renuevan el panorama de los modelos góticos vigentes sino que, además, formarán a la primera generación de arquitectos hispanos llamados a desarrollar, durante el primer cuarto del siglo XVI, una arquitectura "ad modum hispaniae"2.

Así las cosas, a la sombra de estas fábricas castellanas- fundamentalmente las canterías catedralicias de Toledo, Burgos, Segovia, Salamanca, Palencia, Oviedo y Sevilla- y merced a sus arquitectos foráneos, se formarán los principales maestros hispanos quienes, entre fines del siglo XV y principios del XVI, a través de su actividad, consolidarán el complejo fenómeno de la cantería peninsular. De entre ellos, destacaron los canteros cántabros 3 -trasmeranos de la montaña- y vascos ${ }^{4}$-guipuzcuanos y vizcaínos-, clasificados bajo el rubro de maestros del norte, quienes trabajarán en las mejores y más prestigiosas cuadrillas, a veces dirigidas ya por sus propios paisanos. Artistas de la talla de Juan Gil de Hontañón (h. 1470-1526) supieron combinar las doctrinas de los dos mejores arquitectos extranjeros en la Castilla tardomedieval- Juan Guas, díscipulo a su vez de Hanequín Coeman de Bruselas, y Simón de Colonia- siendo, quizá, éste el mejor ejemplo de esto que venimos señalando. ${ }^{5}$

Dadas estas circunstancias, algunos investigadores han puesto de manifiesto la necesidad de abordar estudios sobre los artistas que trabajan a fines del siglo XV en Castilla ${ }^{6}$, pues la figura de estos personajes se encuentra aún desdibujada por la propia Historiografía del Arte, la cual ha venido haciendo más hincapié en el estudio de sus compañeros: los maestros canteros góticos o renacentistas? Urge, por tanto, en la medida en que la propia documentación conservada lo permita, elaborar trabajos monográficos sobre la figura de cada uno de estos individuos de los que, en algunas ocasiones, aunque existen numerosos datos, si bien dispersos, gracias a sus importantes cargos catedralicios y monasteriales, se siguen desconociendo aspectos fundamentales de su actividad.

\footnotetext{
** Antes de comenzar este trabajo, me gustaría expresamente agradecer al Dr. don José Miguel Muñoz Jiménez, director de Investigación Castellológica de la AEAC, el resumen bibliográfico que me ha proporcionado sobre el castillo de Buitrago del Lozoya. Asimismo, a don Juan Pedro Mora, como representante del Ayuntamiento de la villa de Buitrago, por el acceso a los monumentos y por la bibliografía e importantes apreciaciones sobre la historia de la tierra y señorío de Buitrago.

ALONSO RUIZ, Begoña: "Los talleres de las catedrales góticas y los canteros del norte", en Actas del II Encuentro de Historia de Cantabria. Santander, 2005, pp. 707-728. Se trata de un trabajo de mayor alcance en el marco de una investigación subvencionada por la Junta de Castilla y León. Los talleres artísticos de las catedrales castellanas en el último período gótico (1430-1530). [ref. VA 114-04].

2 Como han puesto de manifiesto algunos autores, se trata de una arquitectura tardogótica que no es propia, que no necesitábamos importar, al hundir sus raíces en la arquitectura medieval española y que convive con la otra corriente de renovación análoga, es decir, la renacentista, basada en la recuperación de la tradición clásica. Cfr. MARÍAS FRANCO, Fernando: El Largo siglo XVI. Madrid, 1989. NIETO, Víctor; MORALES, Alfredo José y CHECA, Fernando: Arquitectura del Renacimiento en España, 1488-1599. Madrid, 1989.

Vid. AA.VV: Artístas cátabros de la Edad Moderna. Su aportación al Arte Hispánico. (Diccionario biográfico-estadístico). Santander, 1991.

${ }_{4}$ Cfr. BARRIO LOZA, José Ángel y MOYA VALGAÑÓN, José G: "El modo vasco de producción arquitectónica en los siglos XVI-XVIII", en Kobie (Grupo espeleológico vizcaíno) 10. Bilbao, 1990, pp. 283-369. IDEM: "Los canteros vizcaínos (1500-1800): Diccionario Biográfico", en Kobie, 11. Bilbao, 1981, pp. 173-282.

5 En la actualidad es Begoña Alonso la que trabaja más exhaustivamente en la figura del maestro montañés y su círculo. Vid. ALONSO RUIZ, Begoña: "Juan Gil de Hontañón en Segovia: Sus comienzos profesionales", en Boletín del Seminario de Estudios de Arte y Arqueología, 66. Valladolid, 2000, pp.153-162. IDEM: "De la capilla gótica a la renacentista: Juan Gil y Diego de Siloé en la Vid", en Anuario del Departamento de Historia y Teoría del Arte, XV. Madrid, 2003, pp. 45-57. ID: "El cimborrio de la Magna Hispalense y Juan Gil de Hontañón”, en Actas del IV Congreso Internacional de Historia de la Construcción. Cádiz, 2005, pp. 21-33.

6 En este sentido, el profesor Bango Torviso señalaba: “Entre las muchas asignaturas pendientes de nuestra historiografía, es ésta una de las más trascendentes, pues la falta de una exacta definición de la trayectoria del maestro (Juan Guas) nos está induciendo a una visión muy sesgada del arte de la época". Cfr. BANGO TORVISO, Isidoro: "Simón de Colonia y la ciudad de Burgos. Sobre la definición estilística de las segundas generaciones de familias de artistas extranjeros en los siglos XV y XVI", en Actas del Congreso Internacional sobre Gil de Siloé y la escultura de su época. Burgos, 2001, p. 51.

7 Recientemente, la profesora Begoña Alonso se hace eco de toda esta problemática y, desde la elaboración de su Tesis Doctoral: Una familia de arquitectos góticos en el Renacimiento Español: Los Rasines. Madrid, 2000, viene centrando su línea de investigación en el estudio de la cantería peninsular del tardogótico y sus protagonistas: los maestros canteros.
} 
Si bien es verdad que, en esta última década, se han dado pasos importantes en el conocimiento de estos individuos, hay que reconocer que la reciente Historiografía del Arte ha centrado más su interés en los maestros vinculados con el círculo real y, sobre todo, con las altas esferas eclesiásticas empecinadas en estos momentos en el levantamiento de las grandes canterías catedralicias castellanas. Por ello, se han dejado prácticamente olvidadas el estudio de las no menos importantes empresas del tardogótico patrocinadas por la poderosa nobleza castellana que, con el fin de promocionar el linaje, ávidas de poder e imitando la magnificencia real, en la cual se veían reflejadas, demandaron también la presencia de importantes artistas hispanos.

En este sentido, el linaje de los Mendoza, a través de sus distintas ramas familiares, destacó por la importante labor de mecenazgo que desarrolló en Castilla, para los que tuvieron que trabajar una amplia nómina de artistas. Sin embargo, lejos de ese "totum revolutum", como en su día lo definiera Muñoz Jiménez ${ }^{9}$, que conllevaría el abordar un estudio general del patronazgo llevado a cabo por sus diversos miembros, por cuanto plantearía problemas de estilos, obras y artistas, nosotros venimos centrando nuestro interés en el estudio de un "brazo mendocino": la Casa Ducal de Medinaceli.

Don Luis de la Cerda y Mendoza (1443-1501), primer duque de Medinaceli, era hijo de doña Leonor de la Vega, una de las hijas del primer marqués de Santillana, don Iñigo López de Mendoza (1398-1458). Por tanto, era sobrino del Cardenal don Pedro González de Mendoza (1428-1495) -de quien descienden los príncipes de Melito y marqueses de Cenete-, sobrino también de don Diego Hurtado de Mendoza (1415-1479), primer duque del Infantado y de don Lorenzo Suárez de Figueroa, primer conde de Coruña y vizconde de Torija. Del mismo modo, primo de don Íñigo López de Mendoza (1440-1515), II conde de Tendilla, de quien arranca también el marquesado de Mondéjar. (Ilus. 1).

Atendiendo a lo hasta aquí expuesto, tendríamos que Medinaceli, Infantado, Melito, Cenete, Coruña, Tendilla y Mondéjar conformarían los distintos brazos (títulos y casas) de un mismo tronco familiar, los Mendoza. Aunque si bien es verdad, siguiendo la propuesta de Muñoz Jiménez, que el estudio del patronazgo de la familia Mendoza debe abordarse por Casas nobiliarias -Infantado, Medinaceli y Tendilla ${ }^{10}$ - no estaría de más recordar cómo, en la mayoría de las ocasiones, resultaba totalmente frecuente que un maestro o un mismo taller trabajara para los distintos miembros o ramas de una misma familia. Estaríamos, por tanto, ante idénticos modelos que marcarían el "gusto" familiar, hecho que, a la postre, nos obligaría, al menos, a tener que realizar una valoración de conjunto.

Estas son las circunstancias que envuelven a la figura del maestro cantero vizcaíno Martín de Gamecho. En este sentido, la documentación conservada en los principales archivos nobiliarios españoles ${ }^{11}$, permiten acercarnos a un artista cuya trayectoria profesional pareció transcurrir al servicio del clan mendocino. Vinculado con las obras de mecenazgo desarrolladas por los duques de Medinaceli y duques del Infantado, sus trabajos ponen de manifiesto una personalidad singular que merece ser considerada.

\section{Hacia una aproximación biográfica}

La larga tradición en el oficio de la piedra habría permitido la pronta llegada de los canteros del norte peninsular - de modo global vascos y cántabros- a las grandes canterías castellanas. Al calor de estos talleres recibieron una sólida formación que les permitió, en los primeros años del siglo XVI, integrarse en las mejores y más prestigiosas cuadrillas del momento.

\footnotetext{
8 En este sentido, Begoña Alonso ha puesto de manifiesto cómo artitistas de la talla de Simón de Colonia o Juan Gil de Hontañón, trabajaron también al servicio de una familia nobiliaria como los Velasco, condestables de Castilla y condes de Haro, más tarde duques de Frias. Cfr. ALONSO RUIZ, Begoña: "Arquitectura y Arte al servicio del poder. Una visión sobre la Casa de Velasco durante el siglo XVI", en Patronos y Coleccionistas. Los Condestables de Castilla y el Arte (Siglos XV al XVII). Valladolid, 2005, pp.123-206.

9 Cfr. MUÑOZ JIMÉNEZ, José Miguel: "El Cardenal Mendoza (1428-1495) como promotor de las artes", en Wad-al-Hayara, 22. Guadalajara, 1995, pp. 37-54.

10 El agudo investigador propone también el estudio de las obras patrocinadas por la Casa de Pastrana, aunque advierte que su actuación es posterior en el tiempo, al enmarcarse dentro del reinado de Felipe II. Cfr. MUÑOZ JIMÉNEZ, José Miguel: El Cardenal Mendoza...; opus.cit. p.42.

11 (A)rchivo (D)ucal de (M)edinaceli. Archivo Histórico. (Toledo). (A)rchivo (H)istórico (N)acional. Sección Nobleza. Osuna. (Toledo).
} 


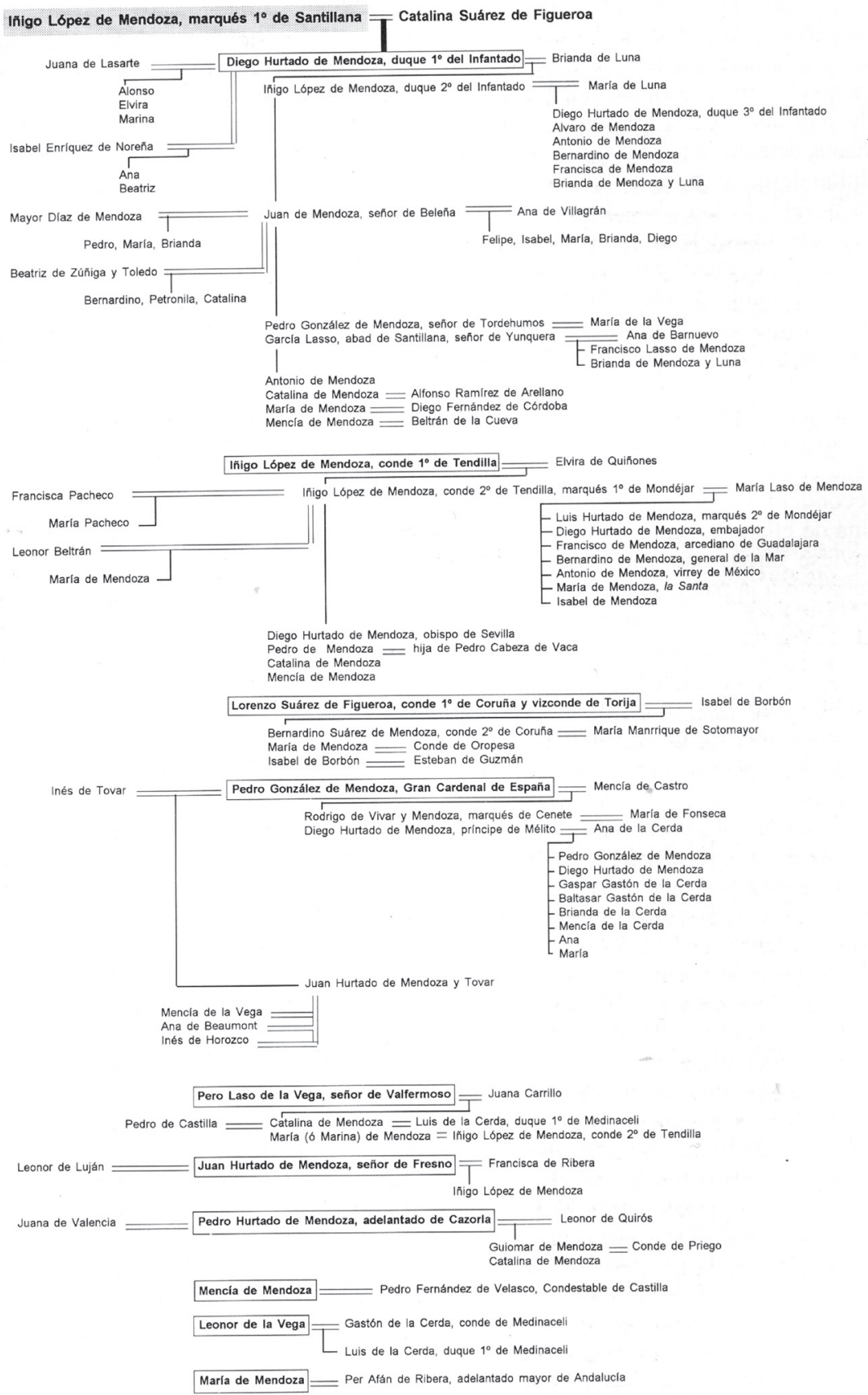

Ilustración 1. Los Mendoza durante la 2/2 del siglo XV. Descendencia y entronques familiares desde don Íñigo López de Mendoza, primer marqués de Santillana. Véase especialmente Infantado, Medinaceli y Tendilla. (Layna Serrano, 1942). 
Así las cosas, éstas debieron ser las circunstancias personales y profesionales que rodearon a nuestro protagonista, el maestro cantero Martín de Gamecho. Lanzado, como el resto de sus colegas, a la emigración, procedía de la pequeña localidad vizcaína de Gamecho, tal y como lo testimonia el origen vasco conservado en su apellido ${ }^{12}$. De hecho, como ya nos señalaran Barrio Loza y Moya Valgañón, la identificación entre el apellido y el lugar de nacimiento era la única manera de conservar su identidad euzkaldún la cual, una vez avecindado en Castilla, quedaba muy mixtificada por matrimonios con mujeres castellanas ${ }^{13}$.

En este mismo orden de cosas, tenemos noticia de otros canteros procedentes de la misma localidad que, aunque algo posteriores en el tiempo, desconocemos si pudieron tener una vinculación familiar con el maestro que nos ocupa. Así, en 1549 un Juan de Gamecho trabajaba en la iglesia de Pampliega (Burgos), por cuyas labores de cantería recibía 2.193 maravedíes. En 1550, la documentación vuelve a registrar sus labores durante 61 días $^{14}$.

En principio, es poco lo que podemos apuntar sobre los inicios profesionales de Martín de Gamecho y sobre el círculo o taller en el que pudo formarse. No obstante, sí es posible especular y establecer algunas hipótesis de acuerdo con ciertos datos documentales. En este sentido, como demostraremos a lo largo de estas páginas, al menos, desde 1514 Gamecho se encontraba trabajando al servicio del III duque del Infantado, don Diego Hurtado de Mendoza y Luna (1461-1531), en lo que parecen ser unas importantes labores de mejora y ampliación del palacio-alcázar del señorío de Buitrago del Lozoya. Desconocemos la fecha exacta en la que se debieron iniciar estas tareas canteriles, aunque, gracias a un documento citado por Casaseca ${ }^{15}$, sabemos que en ellas estuvo implicado Juan Gil de Hontañón (h.14701526), pues según el investigador ocupó el cargo de "maestro de obras del duque del Infantado"16. El hecho de que el maestro de Rasines tuviera vinculación con tierras segovianas- Buitrago del Lozoya pertenecía en estos momentos a la jurisdicción de Segovia-, ha permitido, además, a Begoña Alonso matizar algunas hipótesis ya conocidas, señalando, muy certeramente, cómo sus primeras intervenciones profesionales figuran vinculadas a la ciudad "llave de Castilla" ${ }^{17}$ y a su área de influencia ${ }^{18}$.

Sea como fuere, al contrastar el documento citado por Casaseca, comprobamos cómo éste sólo señala el hecho por el cual el testamentario de Juan Gil de Hontañón, el a su vez colega, García de Cubillas, ordenaba a Juan de Ribera, escribano y vecino de Rascafría, que cobrara de la hacienda del duque del Infantado la cifra de 25.000 maravedíes, los cuales se le adeudaban a Hontañón "de çierta obra que él hizo en su casa de la villa de Buitrago". Estas cantidades, según una cláusula que el maestro montañés había fijado en su testamento, debían ser repartidas a partes iguales entre sus herederos y el propio Juan de Ribera ${ }^{19}$. Por tanto, nos movemos sobre un terreno poco firme: nada se especifica sobre el cargo que ocupaba el maestro, y poco o nada conocemos sobre la naturaleza de esos trabajos en Buitrago.

\footnotetext{
12 No obstante, debe señalarse también la presencia de artistas del siglo XVI con apellidos toponímicos sin que éstos coincidan con los lugares de sus respectivos nacimientos.

13 BARRIO LOZA, José y MOYA VALGAÑÓN, José: El modo vasco de...; opus.cit. pp.288 y ss.

4 BARRIO LOZA, José y MOYA VALGAÑÓN, José: Los canteros vizcaínos...opus.cit. p.214.

5 CASASECA, Antonio: Rodrigo Gil de Hontañón (Rascafría, 1500-Segovia- 1577). Salamanca, 1988, pp.25, nº. 14. IBIDEM. pp. 25 y 88.

7 Segovia era considerada por Isabel la Católica como "llave de Castilla y eslabón para su Corona”. Cit. COLMENARES, Diego de: Historia de la insigne ciudad de Segovia y Compendio de las Historias de Castilla, t. II. Segovia, 1984, p.97.

18 ALONSO RUIZ, Begoña: Juan Gil de Hontañón en Segovia...; opus.cit. pp. 153-162.

19 Segovia. 1526, junio, 19. "Sepan quantos esta carta de poder vieren como yo Garçía de Cubillas maestro / de cantería estante en la noble çibdad de Segovia vezino de Matienço / del Valle de Ruesga en nombre de la mugier e hijos e herederos de Juan Gil / de Hontañón maestro de cantería defunto que dios aya e como su testamentario e / para el cumplimiento de su memoria o- / torgo e por virtud del poder que por el testamento del dicho Juan Gil / de Hontañón a mi fue dado otorgo e conozco por esta presente carta que / he e tengo e según que mejor e más cumplidamente lo puedo e devo dar e / otorgar de derecho e más puede e deve valer a vos Juan de Ribera escribano de sus / Magestades e vecino de Rascafria juredicción desta çibdad que estoy avsente bien ansý como / si fuésedes presente espeçialmente para que por mí e en my nombre e para / cumplir la memoria del dicho Juan Gil de Hontañón podades demandar rreçebir e aver e / cobrar del ylustre e muy magnífico señor el señor duque del Ynfantazgo o de otra / qualesquier persona que por su señoría lo aya de dar e pagar veynte e çinco myll / maravedís que su señoría debe y es obligado a dar e pagar al dicho Juan Gil de Hontañón / de çierta obra que él hizo en su casa de la villa de Buitrago los cuales dichos / maravedís el dicho Juan Gil de Hontañón mando cobrar a vos el dicho Juan de / Ribera en mitad para vos mismo e la otra mitad para el dicho Juan Gil de / Hontañón e para sus herederos según que se contiene en una cláusula /del dicho su testamento a que me refiero el qual vos doy e entrego oregi- / nalmente según e como él le hizo e otorgó para que lo cobréis los / dichos maravedís según dicho es". Cfr. AHP.Segovia. Protocolo n. 54, pp. 684-685.
} 
Podemos afirmar, sin embargo, basándonos en la claridad del protocolo notarial citado por Casaseca, la vinculación de Juan Gil de Hontañón con la Casa del Infantado. Además, fuera o no "maestro de obras del duque", lo cierto y verdad es que esta coyuntura habría favorecido su relación con tierras alcarreñas ${ }^{20}$. De hecho, siguiendo el exhaustivo trabajo de Pérez Villamil, es posible afirmar que el maestro de Rasines hubiese visitado la catedral de Sigüenza (Guadalajara) en 1500, junto a Cristóbal de Adonza "para entender en la obra de la portada de dicha catedral" 21.

De ser así ¿desde cuándo aparece vinculado con el Infantado?. En principio, nada podemos apuntar a este respecto, aunque sí cabe especular con los años de la primera década del siglo XVI. De acuerdo con Begoña Alonso, en octubre de 1512 el maestro ganaba un pleito en la Real Chancillería de Valladolid contra los canteros de su cuadrilla, García del Mogro y Pero Gil, en relación a ciertas cantidades recibidas por obras en la iglesia de Santa María del Castillo de Buitrago del Lozoya ${ }^{22}$.

Al contrastar esta información, comprobamos cómo, efectivamente, el pleito fue ganado por Juan Gil de Hontañón contra el cantero García de Mogro, vecino de Buitrago, quedando éste obligado a dar fianzas por la importante cifra de 150.000 maravedíes, para realizar la obra de la capilla de la iglesia de Santa María del Castillo de Buitrago del Lozoya ${ }^{23}$.

A juzgar por la recopilación de estos datos documentales, el III duque del Infantado estaba acometiendo una mejora de obras en los principales edificios de la villa, es decir, el palacio-alcázar y la iglesia, cuyos orígenes parecen datar de la primera mitad del siglo XV, pues habían sido levantados en época de su bisabuelo, el primer marqués de Santillana, don Íñigo López de Mendoza. Así, el responsable de esta empresa era el maestro cántabro Juan Gil de Hontañón quien, tras ganar el citado pleito a su cuadrilla, pronto pudo quedar desvinculado de estas obras. No obstante, tras este suceso, no estaría de más recordar también las enormes responsabilidades que tendría, pues entre 1513 y 1519 sería maestro mayor de la Magna Hispalensis ${ }^{24}$.

Sea como fuere, desconocemos el alcance de las intervenciones de Hontañón en las obras del señorío de Buitrago, así como el estado en el que debió dejar éstas tras su marcha. Lo cierto y verdad es que, ya en 1514, Martín de Gamecho se comprometía a desarollar ciertos trabajos en el conjunto del alcázar-palacio. A falta de referencias concretas, por el funcionamiento de la cantería de la época, cabría especular con la hipótesis de que el artista hubiese pertenecido a la cuadrilla del maestro cántabro, asumiendo las labores de cantería tras su marcha de Buitrago. Con ella, también, pudieron haber tenido cierta relación los canteros Ortuño de Garnica y García de Liébana, ya vinculados con Gamecho desde sus trabajos en Medinaceli ${ }^{25}$. En cualquier caso, no estaría de más recordar cómo el maestro de Rasines habitualmente aparece trabajando con maestros cántabros de los valle orientales.

En definitiva, éstos y otros importantes aspectos serán valorados y analizados a continuación, en el contexto de los trabajos de cantería en los que se vio implicado la figura del maestro Martín de Gamecho.

\footnotetext{
20 Desde Guadalajara, los Mendoza dirigían el enorme patrimonio atesorado en tierras alcarreñas, donde disponían de 90.000 vasallos, y controlaban el obispado de Sigüenza.

21 Cfr.PÉREZ VILlAMIL, Manuel: Estudios de Historia del Arte. La Catedral de Sigüenza. Madrid, 1889, pp. 465-466.

22 Cit. ALONSO RUIZ, Begoña: Arquitectura y arte...; opus.cit. p. 142, nota. 62.

3 Valladolid, 1512, octubre. 23. "En el pleyto que es en- / tre Juan Gil de Hontañón cantero e su procurador en su nombre de la una / parte e García Mogro vecino de Lozoya e su procurador en su / nombre de la otra fallamos atentos los autos e meri- / tos del proceso de este pleyto que debemos condenar e conde- / namos al dicho García Mogro a que del día que con la carta esecu- / toria de esta nuestra sentencia fuere registrado fasta nueve días pri- / meros siguientes de fianças legas llanas e abonadas al dicho / Juan Gil de Hontañón cantero las quales se obliguen en / forma devida de derecho y le dar e pagar o a quien su poder / oviere los çiento e çinquenta myll maravedís sobre que es este / pleyto para la obra de la capilla de la yglesia de Nuestra Se- I ñora Santa María del Castillo de la villa de Buytrago / e non dando las dichas fianças condenamos al dicho García Mo- / gro en los dichos çiento e çinquenta myll maravedís para hazer / e acabar la dicha obra con costas [...]”. Cfr. A.R.Ch.Valladolid. Registros, Reales Ejecutorias, C-279-4

${ }^{24}$ Sobre su intervención en la Catedral de Sevilla, véanse: RODRÍGUEZ ESTÉVEZ, Juan Clemente: Los Canteros de la Catedral de Sevilla. Del gótico al Renacimiento. Sevilla, 1998, pp. 339-355. Asimismo, ALONSO RUIZ, Begoña: El cimborrio de la Magna Hispalensis...; opus. cit. pp. 21-33.

25 A.D.M. Sección Archivo Histórico. Leg. 183, nº 3.
} 


\section{Trabajos para la Casa Ducal de Medinaceli}

El linaje de los "de la Cerda", una estirpe nobiliaria de origen real desbancada del trono castellano-leonés a fines del siglo XIIII ${ }^{26}$, logró conseguir, tras la entronización de la dinastía Trastámara, un estado unificado en torno a la villa de Medinaceli, en las cercanías de la frontera de Aragón, con el título de condado, en $1368^{27}$.

A partir de entonces, los sucesivos condes de Medinaceli desarrollarán una política destinada a ensanchar de manera paulatina sus estados, gracias a la incorporación de dominios próximos y limítrofes permutados con sus antiguos señoríos más distantes ${ }^{28}$. Junto a ello, en 1479, los Reyes Católicos le conceden la dignidad de ducado ${ }^{29} \mathrm{y}$, a partir de entonces, el estado acabaría configurando, a lo largo del siglo XVI, sus máximos perfiles territoriales.

Es en este contexto cuando, el ya mencionado I duque de Medinaceli, don Luis de la Cerda y Mendoza (vid.Ilus.1), comienza a desarrollar un proyecto arquitectónico y urbanístico sobre Medinaceli, definiendo un área nobiliaria de calidad, conseguida a través de la construcción del nuevo palacio y su plaza representativa, que la convertirían en una villa ducal plena ${ }^{30}$.

Pero la Medinaceli de aquellos años finales del siglo XV no sólo era la sede del ducado del mismo nombre, sino que gozaba también del privilegio de ser cabeza de uno de los arciprestazgos de los que se componía el Obispado de Sigüenza, al cual pertenecía, junto con Atienza, Berlanga de Duero, Cifuentes o Molina de Aragón.

Este hecho, junto a las necesidades de la población ${ }^{31}$, debió impulsar la nueva reorganización parroquial de la villa, pues algunos de los templos estaban abandonados y otros sin uso litúrgico, por estar muy apartados del núcleo urbano. Al abrigo de estas circunstancias, se promovió una reunión de todas las parroquias en la que se acordó que serían demolidas en su mayoría, en la principal de Santa María, para acordar la construcción de un nuevo templo.

La construcción del nuevo templo, consagrado a Santa María de la Asunción, debió realizarse sobre la vieja y modesta fábrica de Santa María, gracias a la iniciativa ducal de don Luis de la Cerda. Aunque desconocemos la fecha del inicio de las obras, quizá a fines de la década de 1490, éstas debieron prolongarse durante el mayorazgo de su hijo, don Juan de la Cerda (1501-1544), II duque de Medinaceli,

\footnotetext{
26 A ello dice Fernández de Bethencourt: "Esta gran familia no tomó su nombre, tan original y extraño, del dominio de la tierra reconquistada, como lo hicieron en su gran mayoría las otras razas feudales españolas y extranjeras, sino de una circunstancia personalísima de su fundador el hijo mayor del rey de Castilla Alfonso X "el Sabio" e inmediato sucesor suyo, el infante heredero don Fernando, que nació con un pelo largo o "cerda" en el pecho, recibiendo por ello de sus contemporáneos el sobrenombre de "Infante o Príncipe de la Cerda" y que después, en recuerdo y memoria suya, sus descendientes tuvieron a honor llevar como apellido aquel mote singular, o como se decía en su tiempo, aquella alcuña". Cfr. FERNÁNDEZ DE BETHENCOURT, Francisco: Historia Genealógica y heráldica de la monarquía española, casa real y grandes de España. Tomo V. Madrid, 1904, pp. 4-5.

27 El título de Conde fue concedido por el rey Enrique II a Bernal de Bearne- hijo bastardo de Gastón Febo III, conde de Foix y vizconde soberano de Bearne-, en 1368. Cfr. FERNÁNDEZ DE BETHENCOURT, Francisco: opus.cit. p.175. El privilegio recaía sobre una villa de realengo, es decir, Medinaceli (Soria) y sus 107 aldeas, que constituían lo que los propios documentos llaman "el común de Medinaceli". Vid. PARDO RODRÍGUEZ, María Luisa: Documentación del Condado de Medinaceli (1368-1454). Soria, 1993, p. 28.

${ }_{28}$ Un amplio estudio sobre esta cuestión en los trabajos de SÁNCHEZ GONZÁLEZ, A: Linajes y Estados de la Casa Ducal de Medinaceli. Estructura de su Memoria Archivística". Tesis Doctoral inédita. Sevilla, 1989. Facultad de Geografía e Historia. Universidad de Sevilla. IDEM: Medinaceli y Colón, la otra alternativa al descubrimiento. Madrid, 1995. ID: Medinaceli y Colón. El Puerto de Santa María como alternativa del viaje de descubrumiento. El Puerto de Santa María, 2006.

29 El documento se encuentra publicado en PAZ Y MELIA, Antonio: Serie de los más importantes documentos del Archivo y Biblioteca del Excmo.Sr.Duqe de Medinaceli. Madrid, 1915, Tomo I. Lámina 16. Asimismo, SÁNCHEZ GONZÁLEZ, Antonio: Medinaceli y Colón. El Puerto...; opus.cit. pp. 356-358.

30 Sobre Medinaceli como tipología de villa ducal plena, junto a Baena, Béjar, Gandía, Guadalajara, Lerma, Medina de Rioseco y Pastrana, ha reflexionado Esther Alegre Carvajal y ofrece, para cada caso, una teoría sobre su evolución y sobre los diferentes matices que presenta. Cfr. ALEGRE CARVAJAL, Esther: Las villas ducales como tipología urbana. Madrid, 2004. Sobre Medinaceli véanse especialmente las pp. 221-232.

31 A lo largo de la época medieval, Medinaceli había experimentado un fuerte crecimiento demográfico y económico, conviertiéndose en el centro neurálgico y comercial de la amplia área del valle del Jalón. Sobre las circunstancias que rodean a Medinaceli en época medieval véanse PARDO RODRIGUEZ, María Luisa: opus.cit. Asimismo, BLANCO FREIEIRO, Antonio: "Medinaceli", en Historia 16, n'. 51. Madrid, 1980, pp. 99-101. Junto a ello, la propia Casa Ducal contribuirá a este auge eximiéndola del pago de la alcábala y dictando ordenanzas para la buena marcha económica de la villa. Un extracto de los documentos en GONZÁLEZ MORENO, Joaquín: Catálogo de los documentos de la villa de Medinaceli. Soria, 1972.
} 
siendo el encargado, junto con los testamentarios de su padre, de finalizar las mismas, pues así lo dejaba ordenado el duque don Luis en una de las cláusulas de su testamento: "Yten por quanto yo mandé hazer e edeficar de nuevo la yglesia de nuestra / Señora la Virgen María de la my villa de Medinaçeli e está aún / por acabar çierta parte della mando que la fagan acabar mis testa- / mentarios" (Cogolludo, 2 de noviembre de 1501$)^{32}$.

Con posterioridad, en 1563, el edificio fue elevado a rango de Colegiata- mediante bula dada por el pontífice Pío $\mathrm{V}^{33}$ - hecho que motivó un pleito con el obispado de Sigüenza, quien se oponía a tal dignidad, y que fue resuelto a favor de la misma, en $1566^{34}$. La consecución del rango de Colegiata debió motivar el que los duques fijarán en ella el panteón familiar, construyendo una cripta bajo su Capilla Mayor. Además, en 1622, la falta de espacio en ella habría determinado la construcción de sendos armarios funerarios en el altar mayor ${ }^{35}$. En palabras de Alegre Carvajal, ello hizo posible el desarrollo de un proyecto ceremonial y festivo con un sentido religioso y barroco muy acusado ${ }^{36}$. A la postre, la Colegiata de Medinaceli acabaría convirtiéndose en el panteón oficial de la Casa Ducal ${ }^{37}$.

Sea como fuere, el resultado fue un espacioso edificio tardogótico de nave única, muy elevada, cubierta con bóvedas de crucería de distintas soluciones, con tres tramos y presbiterio. El posterior de los tramos correspondiente al coro bajo, mientras que los dos restantes quedan libres para el culto y se separan del presbiterio por una reja de grandes dimensiones, elevado éste mediante una grada sobre el nivel de la iglesia. Cada uno de estos tramos se comunican, a través de aberturas practicadas en los muros de la nave central, con dos capillas laterales que, situadas en los lados, hacen de naves secundarias sin ser tales. Éstas deben obedecer a la reforma barroca del templo, llevada a cabo entre 1633 y $1675^{38}$. (vid. Ilus. 2 y 3 )

A la muerte de don Luis de la Cerda, en 1501, las obras en el templo debían marchar a buen ritmo. Ello se supone por el conjunto de libranzas que por orden de los testamentarios del finado duque, Álvaro Carrillo de Albornoz y Pedro de Castilla, registran el pago a los distintos maestros empleados en la obra, entre 1503 y $1509^{39}$.

En cualquier caso, suponemos que don Luis de la Cerda alcanzó a ver terminadas la mayor parte de las obras del templo e incluso debió verse implicado en el concierto para la ejecución del primitivo retablo de su altar mayor, firmado ante el escribano de Medinaceli Hernando de la Cal. Probable diseño de Lorenzo Vázquez, quien con posterioridad tasó toda la obra de talla y pintura, en el intervinieron los entalladores Francisco de Coca y Antonio Flores y el prestigioso pintor Hernando Rincón de Figueroa. Las importantes cantidades en las que Vázquez cifró la tasación de la obra, 100.000 maravedíes las labores de talla y 220.000 maravedíes las de pintura, nos hablan de la importancia de la misma ${ }^{40}$. No obstante, de él nada queda, pues fue sustituido por otro de diseño barroco, que perdura en la actualidad, patrocinado por los VIII duques de Medinaceli, don Francisco Tomás de la Cerda y doña Catalina de Aragón Folch de Cardona.

32 Cfr. A.D.M. Sección Medinaceli. Leg. 7 nº. 1. Edit. SÁNCHEZ GONZÁLEZ, Antonio: Medinaceli y Colón, la otra...; opus.cit. pp. 304.309. Aún así, hemos utilizado un traslado de 1502 conservado en los fondos de la nobleza del Archivo Histórico Nacional. Cfr. A.H.N. Sección Nobleza. Osuna. Leg. 2023-8.

33 Cfr. A.D.M. Sección Medinaceli. Leg. 16. nº 2 y 3. Un regesto de los mismos en GONZÁLEZ MORENO, Joaquín: opus.cit. p. 22.

34 Cfr.A.D.M. Sección Medinaceli. Leg. 17. nº 1 al 11. Un regesto de los mismos en GONZÁLEZ MORENO, Joaquín: opus.cit. pp. 24-27.

35 El 27 de enero de 1622, el maestro alarife Juan Ramos declara haber realizado los dos enterramientos que previamente se le habían encargado a ambos lados de la capilla mayor de la Colegiata de Medinaceli. Cfr. A.D.M. Sección Medinaceli. Leg. 20, nº. 61. Además, el archivo ducal conserva unos dibujos de urnas funerarias para la Colegiata de Medinaceli, que fueron publicados por GONZÁLEZ MORENO, Joaquín: opus.cit. p. 48. Lamina II.

${ }_{36}$ Cfr. ALEGRE CARVAJAL, Esther: opus.cit. pp.230 y ss.

37 El 29 de octubre de 1820 los restos mortales de todos los Medinaceli enterrados en Santa María de Huerta- Soria- fueron entregados, con motivo de darse a conocer la orden de desamortización conventual, por el abad fray Miguel Texero al Contador del duque de Medinaceli, para que fueran trasladados a la Colegial de la villa de Medinaceli, donde desde entonces reposan. Cfr. A.D.M. Sección Medinaceli. Leg. 23, n⿳0.81.

38 Cfr. A.D.M. Sección Medinaceli. Leg. 70, nº. 2.

39 Cfr.A.D.M. Sección Archivo Histórico. Leg. 183, nº. 3.

40 Cfr. Todo ello más ampliamente en ROMERO MEDINA, Raúl: "El taller de entalladores alcarreños de Lorenzo Vázquez y el retablo de la Iglesia de Santa María de Medinaceli (1503-1509)", en Boletín del Museo e Instituto Camón Aznar.(2008: EN PRENSA). 

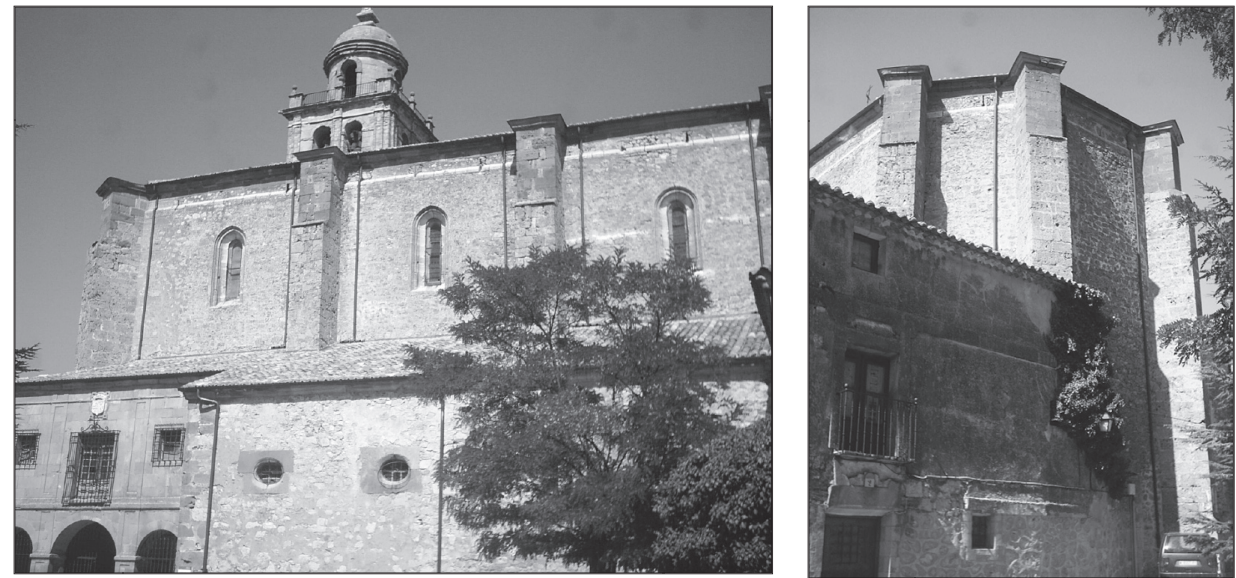

Ilustración 2 y 3 . Vista exterior de la nave (izquierda) y cabecera (derecha) de la Colegiata de Santa María de la Asunción de Medinaceli.

Dadas estas circunstacias, debemos admitir que, tras el fallecimiento del duque don Luis, los trabajos de cantería de la iglesia debían de estar prácticamente terminados. La ejecución del citado retablo, el encargo de los vitrales al vidriero burgalés Juan de Tuesta -siendo su fiador el chantre seguntino Fernando de $\mathrm{Coca}^{41}$ y por los que recibe las cantidades de $6.000^{42}$ y $18.000^{43}$ maravedíes-, y,

${ }^{41}$ Sin lugar. 1503, julio, 3. "Conosco yo el chantre Ferrando de Coca canónygo e obrero de la yglesia de Sigüenza que por quanto I los magníficos señores don Pedro de Castilla e don Álvaro Carrillo como testamentarios del ylustre / señor don Luys de la Çerda duque de Medina que aya santa gloria ovieron mandado dar a Juan de / Tuesta vedriero vecino de Burgos seys myll maravedís para en señal e parte de pago de unas vidrie- / ras que sus merçedes mandan faser para la yglesia de Santa María de la dicha villa de Medina las / quales ha de faser de aquí al día de Sant Myguel e puesto en esta çibdad de Siguenza que yo por / la presente me obligo por my persona e bienes que si no tuviere las dichas vidrieras por / el dicho tiempo ocho días después de los dar e tomar los dichos seys myll maravedís de aquí a / fin del mes de octubre primero que viene deste año de quinyentos e tres puesto en poder de los dichos señores o de la persona que este my conosçymiento me diere en rrenunçia de lo / qual firmé la presente de my nombre e va escripta de my letra. Fecha a honse días de jullio año de myll e quinyentos e tres años. El chantre Ferrando de Coca (rúbrica)”. Cfr. A.D.M. Sección Archivo Histórico.Leg. 183, nº 3.

42 Sin lugar. 1503, julio, 8. "Yo don Juan de la Çerda duque de Medinaçely conde del Puerto de Santa Marýa señor de / Huelva y de Deça y don Pedro de Castilla y don Alvaro Carrillo de Albornoz testamen- / tarios que somos del muy ylustre señor el señor don Luys de la Çerda duque de Medina- / çely nuestro señor que santa gloria aya mandamos a vos Pedro de Tejada nuestro rreçebtor I que de qualesquier maravedís que por nuestro mandado aveys rreçebido y vos son cargados en este / añp de la fecha de esta carta de libramyento dedes a Juan de Tuesta maestro de vidrieras / veçino de Burgos seys myll maravedís los quales le mandamos dar para en cuenta y parte de / pago de çinco vedrieras que ha de hazer por nuestro mandado para la yglesia de / Santa María de la vylla de Medina segúnd la carta del chantre de Soria y / está obligado ante Diego de Soria escriuano y dadgelos y pagadgelos y / tomad su carta de pago con la qual y con esta mandamos que vos sean rrecebidos y pasa- I dos en cuenta los dichos seys myll maravedís. Fecha a ocho días del mes de jullio de / myll e quinyentos e tres años. El duque (rúbrica). Pedro de Castilla (rúbrica)”. Cfr. A.D.M. Sección Archivo Histórico. Leg. 183, nº. 3.

${ }_{43}$ Sin lugar. 1505, junio, 27. "Yo don Juan de la Çerda duque de Medinaçely conde del Puerto de Santa Marýa señor delas villas de I Cogolludo y Deça y don Pedro de Castilla y don Álvaro Carrillo de Albornoz testamentarios que so- / mos del muy ylustre señor el señor don Luys de la Çerda duque de Medinaçely que santa gloria / aya nuestro señor mandamos a vos Pedro de Tejada nuestro rreçebtor que de los maravedís que rreçebistes por / nuestro mandado y os an de ser cargados en el año pasado de myll y quinyentos y tres años / dedes a Juan de Tuesta vedriero veçino de Burgos diez y ocho myll maravedís los quales le / mandamos dar para cumplimyento de pago de veynte y quatro myll maravedís que ovo de aver por çinco / vedrieras que puso por nuestro mandado en la yglesia de Santa Marýa de la villa de Medina las / quatro dellas en el cuerpo de la dicha yglesia y la una en la sacristanýa della con las armas / de su señoría la una de la ymajen de nuestra señora Santa Marýa y las otras de Santa Catalina y la / otra de Santa Águeda y la otra de San Lázaro y la otra de San Gil con sus asientas / y redes de hierro sobre seys myll maravedís que en vos le mandamos librar y dadgelos / y pagadgelos y tomad su carta de pago con la qual y con esta mandamos que vos sena rreçebi- / dos y pasados en cuenta los dichos diez y ocho myll maravedís. Fecha a veynte e siete días / mes de junyo de myll y quinyentos y cinco años. El duque (rúbrica). Alvaro Carrillo de Albornoz (rúbrica). Pedro de Castilla (rúbrica)”. Cfr. A.D.M. Sección Archivo Histórico. Leg. 183, nº. 3. 
finalmente, el pago de 11.000 maravedíes por los órganos de la iglesia a Alonso de Castilla ${ }^{44}$, parecen corroborar esta hipótesis.

Llegados a este punto del discurso cabría interrogarnos ¿qué trabajos de cantería restaban por hacer?. La documentación conservada nos permite, con la salvedad de carecer de una descripción de la obra ya finalizada, afirmar que éstos eran la tribuna o coro interior del templo y el campanario. Son en estas labores en las que por primera vez tenemos documentada la figura del maestro cantero Martín de Gamecho. Los pagos que el receptor de la obra, Pedro Tejada, ordena librar al mayordomo Juan Ortega en la figura de Gamecho, comienzan el 27 de marzo de 1503 y finalizan el 15 de septiembre de $1504^{45}$. Dadas estas circunstancias, es en este breve período durante el cual, al menos, aparece relacionado con la obra ducal de Medinaceli, ejecutando la tribuna y el campanario de la iglesia.

Aunque ninguno de los dos elementos ha llegado hasta nosotros, pues fueron demolidos y replanteados con las reformas barrocas, podemos hacernos una idea aproximada de los mismos. En este sentido, la tribuna o coro interior, situado a los pies de la nave, tendría la función de comunicar el templo con la torre o campanario del mismo. Las libranzas conservadas permiten conocer que la tribuna fue un proyecto concebido con labores de cantería y carpintería. Los trabajos de cantería fueron ejecutados por Gamecho recibiendo, junto con la obra del campanario, un total de 215.000 maravedíes, más 3.675 maravedíes en concepto de demasías a juicio de los maestros canteros García de Liébana, Ortuño de Garnica y Francisco de Medina ${ }^{46}$. Por su parte, los de carpintería fueron ejecutados por el carpintero montañés Juan del Abad, percibiendo la suma total de 13.200 maravedíes ${ }^{47}$.

Cabe suponer que la tribuna tendría una subida de escaleras y unas columnas de piedra para su sujeción, mientras que la parte superior pudo estar asentada sobre travesaños de madera, adornada con una baranda y suelo de tablones. Por su parte, nada podemos apuntar sobre el aspecto que pudo haber presentado la torre-campanario.

En cualquier caso, aunque la documentación conservada no nos permita obtener mayor información sobre las intervenciones de Martín de Gamecho, ésta sí nos corrobora la presencia del maestro en el área alcarreña- recordamos que Medinaceli era cabeza de uno de los arciprestazgos del obispado de Sigüenza (Guadalajara) y su posterior vinculación, como trataremos a continuación, con el área segoviana, en Buitrago del Lozoya ${ }^{48}$. En este sentido, su figura parece sitiuarse a la sombra de la primera generación de canteros hispanos y, probablemente, de Juan Gil de Hontañón, vinculado a la ciudad de Segovia y su área de influencia desde sus primeras intervenciones documentadas ${ }^{49}$.

\section{Trabajos para la Casa Ducal del Infantado}

A la sombra de los monarcas Trastámara, el linaje de los "Mendoza", oriundo de tierras vascas, conseguía ascender a la cúspide del poder. Así, en 1368, el monarca Enrique II confirmaba al primero de

\footnotetext{
44 Sin lugar. 1502, octubre, 8. "(Cruz) Pedro de Tejada rrecebtor de la hazienda del duque de Medinaçely que santa gloria aya dad a don / Alonso de Castilla onze myll maravedís los quales a de aver por vía determinasión que el licençiado Blazquez hizo juez de todas las pençiones que se an dado por descargo del ánima del duque nuestro señor / que santa gloria aya y por rrazón de unos órganos quel dicho señor duque le era / en cargo e dadgelos e tomad carta de pago con la qual y con esta y avala determinaçión del / licençiado Blazquez los rrecibiremos en cuenta los onze myll maravedís fecha a VIII días de otubre de quinientos e dos años. Pedro de Castilla (rúbrica). Licenciado Bláquez (rúbrica)”. Cfr. A.D.M. Sección Archivo Histórico. Leg. 183, nº. 3.

${ }^{45}$ Cfr. A.D.M. Sección Archivo Histórico. Leg. 183, no . 3. Vid. Apéndice Documental. Docs. nº 1, 2, 3, 4, 5, 6 y 7.

${ }^{46}$ Cfr. A.D.M. Sección Archivo Histórico. Leg. 183, nº. 3. Vid. Apéndice Documental. Doc, nº 7.

${ }^{47}$ 1504, agosto, 29. "Yo don Juan de la Çerda duque de Medinaçely conde del Puerto de Santa Marýa señor de Huelva y de / Deça y don Pedro de Castilla y don Álvaro de Carrillo Albornoz testamentarios que somos del / muy ylustre señor el señor don Luys de la Çerda duque de Medinaçely que santa gloria aya / nuestro señor mandamos a vos Pedro de Tejada nuestro rreçebtor que de qualesquier maravedís que por nuestro manda- / do aveys rreçebido y os an de ser cargados en el año pasado de myll y quinyentos y tres años / dedes a Juan del Abad montañés carpentero treze myll y doszientos maravedís que los an de aver / para ser pagados de la trebuna de madera que hizo por nuestro mandado en la yglesia de Santa / Marýa de la dicha villa de Medina a todas sus costas este año de myll y quinyentos y quatro / años segúnd se contyenen en la obligaçión y asyento que sobre ello pasó ante Diego de / Soria escriuano público en la dicha villa y dadgelos y pagadgelos y tomad su carta de / pago con la qual y con esta mandamos que vos sean rreçebidos y pasados en cuenta los dichos / treze myll y doszientos maravedís. Fecha a veynte y nueve días del mes de agosto de myll y qui- / nyentos y quatro años. El duque (rúbrica).Pedro de Castilla (rúbrica)". Cfr. A.D.M. Sección Archivo Histórico. Leg. 183, nº 3.

48 Aún perteneciendo a la jurisdicción segoviana, la villa y tierra de Buitrago se vinculará muy pronto a Guadalajara, como señorío de los Mendoza.

49 Sobre Juan Gil en Segovia, véase: ALONSO RUIZ, Begoña: Juan Gil en Segovia...; opus.cit. pp.153-162.
} 
sus miembros nacido en Castilla, don Pero González de Mendoza (1340-1385) ${ }^{50}$, los títulos de señor de Hita y Buitrag $0^{51}$. A partir de entonces, amasarían una importante fortuna territorial, merced a la política de alianzas e influencias cortesanas, que se consolidaría en 1475 cuando los Reyes Católicos otorgaron a don Diego Hurtado de Mendoza (1415-17?- 1479), heredero del mayorazgo, el título de duque del Infantado (vid.Ilus.1) . $^{52}$.

Así las cosas, vemos cómo el señorío de Buitrago del Lozoya y su tierra aparece vinculado desde muy temprano a la rama alcarreña de los Mendoza $^{53}$. No obstante, no será hasta época de don Íñigo López de Mendoza (1398-1458) $)^{54}$, cuando, gracias a sus privilegios y mecenazgo, la villa experimente un importante crecimiento urbano y arquitectónico. Fruto de ello, fue la construcción de edificios tan singulares como la iglesia de San Juan y el hospital de San Salvador,hoy desaparecidos, y de otros que perduran como la iglesia de Santa María del Castillo, junto con las reformas en el recinto amurallado de la villa y su castillo-alcázar. En definitiva, con don Íñigo, se dice que Buitrago vivió su mayor época de esplendor, pues comenzó a configurar su morfología urbana, la cual mutatis mutandis ha llegado a nuestros días. (vid.Ilus.4).

Junto a la importante contribución de don Íñigo al engrandecimiento del señorío buitragueño, debe también señalarse el papel que van a jugar sus sucesores, los duques del Infantado, quienes, a pesar de no residir habitualmente en la villa, sí continuarán estableciendo medidas encaminadas tanto a favorecer y consolidar su poblamiento, como a continuar con los programas arquitectónicos ya iniciados.

En este sentido, tradicionalmente se viene admitiendo que las obras comenzadas por don Íñigo en dos de los edificios de la villa- iglesia de Santa María del Castillo y castillo-alcázar- fueron finalizadas por su nieto, don Íñigo López de Mendoza, II duque del Infantado, que murió con el siglo, en el año 1500.

Sin embargo, a la luz de nuevas aportaciones documentales, pensamos que esta hipótesis debe ser sometida a revisión, por cuanto, al parecer, durante el gobierno de don Diego Hurtado de Mendoza y Luna (1500-1531), III duque del Infantado, asistimos a la ejecución de un nuevo programa arquitectónico para completar la fisonomía de estos edificios. Esta empresa debe ser enmarcada en las dos primeras décadas del siglo XVI, participando en las labores de la primera, el cántabro Juan Gil de Hontañón y en la segunda, un posible discípulo, el cantero vizcaíno Martín de Gamecho.

\footnotetext{
50 Nacido en Guadalajara, era hijo de Gonzalo Yañez de Mendoza, el primer Mendoza en dejar las tierras vascas para instalarse definitivamente en tierras guadalcarreñas, y Juana de Orozco.

${ }_{51}$ 1368, enero, 1, Burgos. Cfr. A.H.N. Sección Nobleza.Osuna. C.1652. D.6 (1-2). En 1848, Pascual Madoz recordaba este hecho señalando: "Suena Buitrago en las guerras de Don Pedro de Castilla y su hermano D. Enrique; estaba por áquel y la sitió una de las partidas de éste; su gobernador se resistió con valor, pero llegó a ella el mismo D. Enrique con su ejército, y le fue preciso entregarse (año 1368)". Cfr. MADOZ, Pascual: Diccionario Geográfico-estadístico-histórico de España y sus posesiones de Ultramar. Madrid, 1845-1850. Véase la voz Buitrago.

52 Para el estudio de los Mendoza, véase ARTEAGA Y FALGUERA, Cristina: La Casa del Infantado, Cabeza de los Mendoza. Madrid, 1940, 2 vols. Del mismo modo, LAYNA SERRANO, Francisco: Historia de Guadalajara y sus Mendoza en los siglos XV y XVI. Madrid, 1942. IV tomos. Más recientemente, SÁNCHEZ PRIETO, Ana Belén: La Casa de Mendoza hasta el III duque del Infantado (1350-1531). El ejercicio y alcance del poder señorial en la Castilla Bajomedieval. Madrid, 2001.

53 En cualquier caso, existen disparidad de opiniones a la hora de determinar quién fue el primer señor de Buitrago. Todo apunta a que Pero González de Mendoza recibió por parte de Enrique II la confirmación de una herencia, pues ya en 1289 se menciona que Íñigo López de Orozco era señor de Hita y Buitrago. Sea como fuere, Pero González de Mendoza es el primer señor de la villa que aparece en los documentos reales. Sobre la villa y el señorío de Buitrago resulta fundamental FERNÁNDEZ GARCÍA, Manuel: Fuentes para la historia de Buitrago. 2 vols. Madrid, 1966.IDEM: Buitrago y su tierra. Algunas notas históricas Madrid, 1980. ID: Buitrago y su tierra.Historia religiosa. Madrid, 1984. Asimismo, FLAQUER MONTEQUI, Rafael: Breve introducción a la Historia del señorío de Buitrago. Madrid, 1978. Anteriores los estudios de HERNÁN, Francisco: Buitrago de Lozoya. Madrid, 1970 y TERRASE, Henrri: "Buitrago", en Mèlanges de la Casa de Velázquez. Tome V. Madrid, 1969, pp. 189-205. Más antiguo pero exhaustivo sobre el señorío mendocino y sus protagonistas, vid. LAYNA SERRANO, Francisco: Historia de Guadalajara...;opus. cit. Más recientemente, LOMBANA DOMÍNGUEZ, Nuria: "El enclave estratégico de Buitrago del Lozoya y su evolución histórica (siglos X-XV)", en Orígenes históricos de la actual Comunidad Autónoma de Madrid. La organización social del espacio en la Edad Media. Madrid, 1995, pp.111-126.

54 Nieto de Pero González de Mendoza y primogénito del Almirante de Castilla, don Diego Hurtado de Mendoza, en 1445 sería nombrado marqués de Santillana y conde del Real de Manzanares. Tendrá por hijos a don Pedro González- "Cardenal Mendoza"-, don Pedro Hurtado-"adelantado de Cazorla", don Íñigo López- "conde de Tendilla"- y don Diego Hurtado, sucesor en el mayorazgo y "Ier duque del Infantado". (Vid.Ilus.1). Sobre él existe una amplísima bibliografía, de entre ella véase la obra colectiva AA.VV: El Marqués de Santillana (1398-1458). Los albores de la España Moderna. 4 vols. Hondarribia, 2001. Asimismo, PÉREZ BUSTAMANTE, Rogelio: El marqués de Santillana. Biografía y documentación. Madrid, 1983.
} 


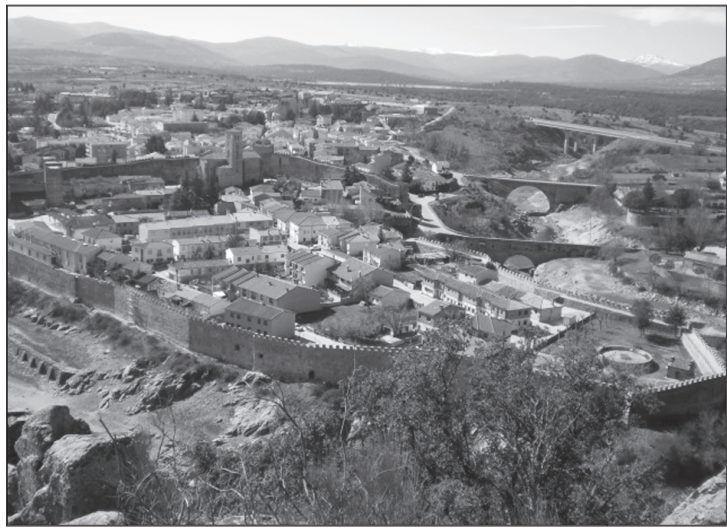

Ilustración 4. Panorámica general del caserío urbano de Buitrago del Lozoya

Sobre los trabajos que vinculan a Juan Gil de Hontañón con el señorío buitragueño, poco podemos apuntar, pues no existe documentación directa al respecto. En cualquier caso, como ya hemos citado, es posible corroborar tanto su participación en las labores canteriles del palacio-alcázar ${ }^{55}$, como en la iglesia de Santa María del Castillo ${ }^{56}$. Sólo la aparición de nuevos documentos, podrán arrojar más luz sobre la figura del arquitecto de Rasines como "maestro del duque del Infantado" y, concretamente, aclarar sus intervenciones en Buitrago. En cualquier caso, la portada principal de la iglesia de Santa María del Castillo- un arco mixtilíneo gótico de tres vueltas encuadrado por alfiz con escudos en las enjutas- nos remite a esta figura clave del tardogótico castellano muy influenciada por el "savoir-faire" de Juan Guas. No cabe duda que el alfiz nos habla, directamente, de esas enseñanzas embebidas y aprendidas de la arquitectura mudéjar toledana. (vid.ilus. 5).

Más información, sin embargo, podemos ofrecer sobre las labores que tuvieron implicado a nuestro protagonista, el maestro cantero Martín de Gamecho, con los trabajos patrocinados por el III duque del Infantado. En cualquier caso, sí debemos señalar que su posible vinculación con el foco de Juan Gil de Hontañón se cimienta sobre un terreno de hipótesis coherentes pero, al fin y al cabo, no dejan de ser hipótesis historiográficas, que deberán ser contrastadas en un futuro próximo.

Sea como fuere, tras su paso por Medinaceli, Martín de Gamecho aparece vinculado, desde al menos 1514, al área segoviana en los trabajos del alcázar-palacio del señorío de Buitrago del Lozoya, patrocinados en estos momentos por el III duque del Infantado ${ }^{57}$. De ellos se ocupará hasta enero de 1521, cuando recibe el último pago de 10.000 maravedíes "para acabar las claraboyas del corredor de Buitrago" 58 . ¿En qué consistieron estos trabajos?. Pasemos, pues, a ilustrarlo.

El castillo de Buitrago de Lozoya refuerza el recinto amurallado de la villa, cerrándolo por el sector sureste $^{59}$. Recientes excavaciones arqueológicas ofrecen una cronología posterior a la construcción de las

55 Vid.notas. 15,16 y 19.

56 Vid. notas. 22 y 23.

57 Sobre la figura de don Diego Hurtado de Mendoza, de la Vega y de Luna, III duque del Infantado, entre otros, consúltese SÁNCHEZ PRIETO, A. B: La Casa de Mendoza...; opus.cit. pp. 298 y ss.

58 Cfr. A.H.N. Sección Nobleza. Osuna. C.1664. D-2. Vid. Apéndice Documental. Doc. nº 18.

59 Sobre el castillo de Buitrago véanse: LAYNA SERRANO, Francisco: Castillos de Buitrago y del Real de Manzanares. Madrid, 1935. DOTOR, Ángel: "Castillos de Madrid y Ávila”, en Revista Geográfica Española, s.n, s.f., pp. 33-39. BORDEJÉ, Federico: "Castillos de la Casa del Infantado",en Castillos de España, 69. Madrid, 1970, pp. 18-37. COOPER, Edward: Castillos señoriales de Castilla. Madrid, 1980, pp. 47-63. IDEM: "Vaivenes de los castillos señoriales de Castilla bajo la Reina Católica", en Artillería y Fortificaciones en la Corona de Castilla durante el Reinado de Isabel la Católica (1474-1504). Madrid, 2004, pp. 449-475. ID: "Castillos señoriales del Reino de Toledo", en Actas del Simposio Espacios Fortificados en la Provincia de Toledo. Toledo, 2004. JIMÉNEZ ESTEBAN, Jorge: Guía de los castillos de Madrid. Madrid, 1987, pp. 46-50 y "Castillos de Madrid", en Castillos de España. León, III, 1997, pp.1746-1749. Finalmente, consúltese la obra realizada por el equipo de Sáez Lara, AA.VV: Castillos, Fortificaciones y recintos amurallados de la Comunidad de Madrid. Madrid, 1993, pp. 132-143. 


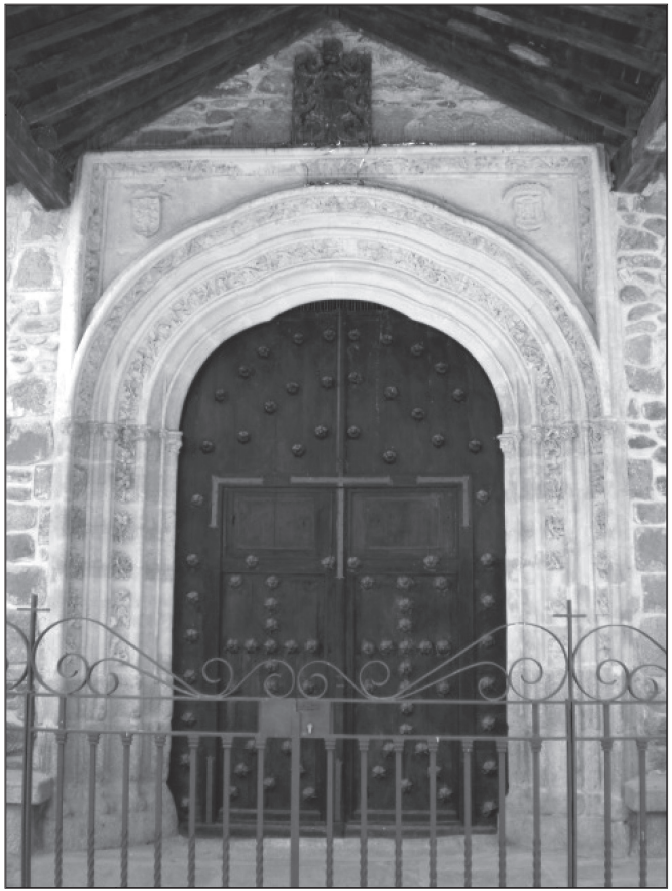

Ilustración 5. Portada occidental de la iglesia de Santa María del Castillo. C.1/4 s.XVI

murallas, es decir, lo sitúan a fines del siglo XIII o principios del XIV ${ }^{60}$. Dibujando en planta un cuadrado de unos cuarenta y cinco metros de lado, presenta ocho torres localizadas en esquinas y zonas intermedias de lienzos, a excepción del lado oriental, sin defensas de este tipo.

Así, este es el recinto que debió limitar el espacio central que albergaba la residencia nobiliaria, que venimos definiendo como palacio-alcázar buitragueño, levantada en tiempos de don Íñigo López de Mendoza, primer marqués de Santillana. De estructura porticada con dos galerías superpuestas en torno al espacio central, las distintas dependencias debieron distibuirse a dos niveles, siendo el inferior el destinado a la zona de servicios y el superior a las estancias y salones privados, cubiertos de bóvedas de ladrillos. Arruinado y convertido muy posteriormente en plaza de toros, en la actualidad se hace dificil imaginar su estructura, pues sólo se observan restos de chimeneas y varios huecos de ventanas ${ }^{61}$. (Vid. Ilus. 6).

A pesar de ello, es de justicia señalar que este conjunto no sólo se debió al primer marqués de Santillana, pues, durante el siglo XVI, continuaron las ampliaciones y mejoras de la mano de su biznieto, el III duque del Infantado. Así, el 20 de mayo de 1514, el maestro de cantería Martín de Gamecho firmaba las condiciones con las que se obligaba a realizar un corredor "alto y baxo en el alcáçar de

\footnotetext{
60 Sobre las excavaciones arqueológicas, JUSTE BALLESTA, Jorge: Proyecto de restauración en el Recinto Amurallado de Buitrago del Lozoya. Memoria Inédita. Dirección General de Patrimonio Cultural de la Comunidad de Madrid, 1986. IDEM: Plan de recuperación integral del recinto amurallado de Buitrago del Lozoya.Dirección General del Patrimonio Cultural de la Comunidad de Madrid. Madrid, 1990. MENA MUÑOZ, Pilar y LÓPEZ DEL ÁLAMO, Paloma: Informe de las Excavaciones Arqueológicas realizadas en el Recinto amurallado de Buitrago del Lozoya. Madrid, 1988 (Inédito). LÓPEZ DEL ÁLAMO, Paloma y RUBIO, M.J: "Las murallas de Buitrago del Lozoya", en Trabajos sobre el Madrid Árabe. Madrid, 1990, pp. 27-34.

${ }_{61}$ En 1781 Antonio Ponz se detiene en él y nos describe su situación señalando cómo se situaba "dentro de la fortaleza, y junto al río, el palacio del señor de la villa (duque del Infantado), del que sólo quedan las paredes maestras muy fuertes, y bien construidas,de surte que pudiera muy bien reedificarse todo lo demás”. Cfr. PONZ, Antonio: Viage de España. Tomo X. Madrid (1781).
} 


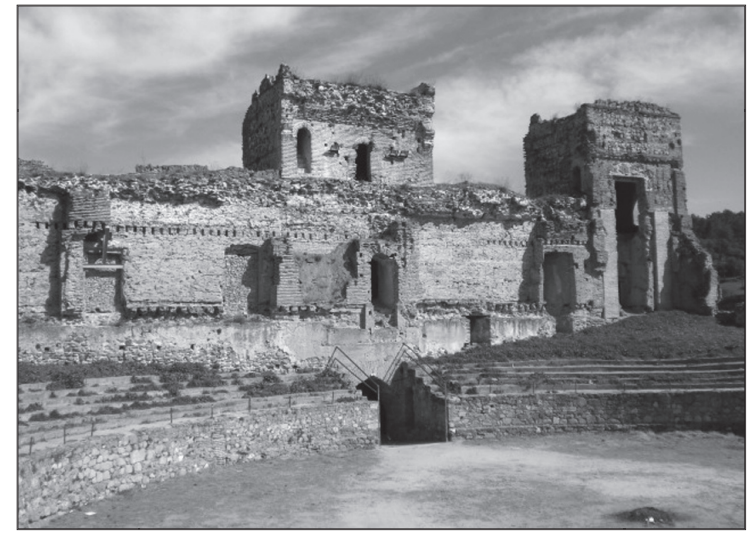

Ilustración 6. Estado actual del interior del alcázar de Buitrago ( marzo, 2008).

la dicha vylla de Buytrago a la parte del río" ${ }^{2}$. En él, además, se dejaba constancia de cómo ciertos elementos, es decir, capiteles y basas de los pilares sobre los que se sustentaban sus ocho arcadas, debían "ser conforme a los que están hechos en el patio de la casa del dicho alcáçar" ${ }^{63}$. No cabe duda, se trataba de completar la estructura que servía de residencia palaciega añadiéndole nuevos elementos, pero respetando la unidad estilística que presentaba ya el conjunto.¿Dónde se situaba el corredor? y ¿qué características presentaba su estructura?

Este nuevo corredor estaba llamado a situarse hacía el sector que miraba al fondo del río, frente a la coracha del recinto (Vid.Ilus.7). Su estructura iba a permitir servir de tránsito entre dos zonas, situándose a lo largo del espacio que separan las torres de este sector, pues "su dicha pared a de ser dende torre a torre todo lo que monta el terrado alto de largo a largo" 64 . Aunque en la actualidad no se conserve, como ocurre con todo lo demás, su estructura debió de ser visible todavía a principios del siglo XIX, pues "el Patriense", manuscrito anónimo que contiene una historia de Buitrago, lo mencionó como "los corredores del río" y señaló que todavía tenía en pie uno de sus arcos y las basas de otros ${ }^{65}$. En cualquier caso, hoy en día los restos de esta estructura son visibles en el entorno del propio recinto. (Vid. Ilus.8).

Por su parte, las condiciones fijadas en el contrato con Martín de Gamecho eran muy claras con respecto a la disposición que debía presentar el corredor, es decir, debía de ser una estructura abierta al exterior, "a la parte del río", que conformaba una doble galería porticada, con balaustrada continua de piedra, de ocho arcos de medio punto sostenidos por pilares redondos de articulación clásica. Incluso se ofrece otra posibilidad, pues "si su señoría quisyere que sean nueve y sea obligado a los haser"66.

Aunque la galería no ha llegado hasta nosostros, y tampoco tenemos documentación gráfica de la misma, hemos de suponer que ésta debió presentar diferencia de tratamiento estilístico en cada piso, pues sabemos que el alto no se pudo acabar "porque su señoría lo mandó faser lo más rrico" 67 . Ello motivó que, mientras el piso bajo fue acabado en la fecha que estipulaba el contrato con Martín de Gamecho, noviembre de 1514, las labores del alto no finalizaron a la fecha y éstas se volvieron a retomar un año después, a causa de que "se hubo de buscar nueva cantería para lo faser" ${ }^{68}$. En cualquier caso, las obras finalizaron en enero de 1521, cuando se terminan de rematar las claraboyas del corredor alto ${ }^{69}$.

${ }^{62}$ Cfr. A.H.N. Sección Nobleza.Osuna.C.1664. D-2. Vid. Apéndice Documental. Doc, nº 8.

63 IBIDEM

${ }^{64}$ Cfr. A.H.N. Sección Nobleza. Osuna. C.1664. D-2. Vid. Apéndice Documental. Doc, nº 8.

65 PATRIENSE, EL: Historia de Buitrago.(18 ??). Biblioteca Nacional de Madrid. Manuscrito.2190.

66 Cfr. A.H.N. Sección Nobleza. Osuna. C. 1664. D-2. Vid. Apéndice Documental. Doc, nº.8.

${ }^{67}$ Cfr. A.H.N. Sección Nobleza. Osuna. C.1664. D-2. Vid.Apéndice Documental. Doc, nº. 14.

68 Ibidem.

${ }^{69}$ Cfr. A.H.N. Sección Nobleza. Osuna. C.1664. D-2. Vid. Apéndice Documental. Doc. nº 18. 


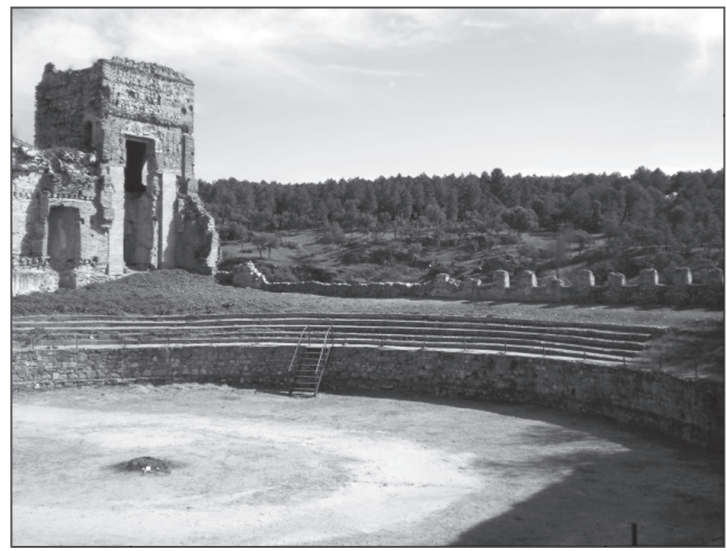

Ilustración 7. Al fondo, sector que ocupó el corredor. Alcázar Buitrago.

Sea como fuere, tampoco podemos precisar sí, efectivamente, se trató de una galería concebida como logia abierta- por otra parte muy en boga en la arquitectura civil tardogótica de la época ${ }^{70}$, por cuanto se trataba de un replanteamiento "ad modum hispaniae" de la versión romana ${ }^{71}$ - o, simplemente, de un corredor similar al de las galerías que corrían alrededor de su patio principal. De hecho, la propia documentación alude a que ciertos elementos de la misma debían guardar semejanza estilística "conforme a los que agora están hechos en los dichos corredores del dicho alcaçar"72. En cualquier caso, es posible pensar en una galería independiente, con una evidente carga simbólica ${ }^{73}$, a las que hizo posible el patio central del alcázar.

¿Cómo era la galería?. En principio, debemos partir de la base de esa cierta diferencia estilística entre la zona alta y baja, aunque quizá más de carácter decorativo que propiamente estructural. De esta suerte, sobre un murete o pretil de "cal y canto" formado por cinquenta tapias, con un grueso total de cinco pies, es decir, 1.40 metros, debían de ir asentadas las basas de los ocho pilares que sustentarían los arcos, sobre los que correría el entablamento. Los pilares, cada uno de una vara de grueso, o sea, 0.84 metros, debían de ser redondos, de tal manera que "los dichos arcos que an de venir sobre éstos an de ser de medio punto" 74 . Sin embargo, se ofrece otra alternativa "y si le pareçiere a su señoría que suban más haser sean de otro punto que sea más sólido porque sea más sygura la obra"75. El conjunto que formaban estas arquerías debían de llevar "sus botaretes de syllería con sus esquinas bivas tan grandes como fuere menester para estribo de los arcos" " . Los refuerzos o contrarrestos que debían de llevar los mismos, debían de ser de "seys pies e medio (de largo) y quatro pies y medio de grueso" 77 , es decir, 1.82 metros de largo por 1.26 metros de espesor. Junto a ello, la propia galería debía de llevar su antepecho

\footnotetext{
70 Arquitectos como Simón de Colonia en Burgos (Casa del Cordón), Lorenzo Trillo en Guadalajara (Palacio del Infantado) y Lorenzo Vázquez de Segovia en Cogolludo, Guadalajara (Palacio de los duques de Medinaceli), revitalizarán este elemento a fines del siglo XV. Begoña Alonso demuestra cómo, a partir del proyecto de la Casa burgalesa del Cordón, el linaje de los Fernández de Velasco tenderá a emplearlo en las construcciones civiles de la familia. Cfr. ALONSO RUIZ, Begoña: Arquitectura y Arte...; opus.cit. pp. 130 y ss.

${ }_{71}$ Cfr. MARÍAS FRANCO, Fernando: “De Madrid á Paris: François Ier et la Casa de Campo", en Melánges de la Casa de Velázquez. París, 1990, pp.26 y ss.

72 Cfr. A.H.N. Sección Nobleza. Osuna. C. 1664. D-2. Vid. Apéndice Documental. Doc. nº. 14.

73 De hecho, el contrato ordena disponer los escudos de los duques en cada arcada de la misma "conforme a los que están en los arcos del patio salvo que an de ser de mayor cuerpo”. Cfr. A.H.N. Sección Nobleza. Osuna. C.1664. D-2. Vid. Apéndice Documental. Doc. $\mathrm{n}^{\circ} .14$.

${ }_{74}$ Cfr. A.H.N. Sección Nobleza.Osuna.C.1664. D-2. Vid. Apéndice Documental. Doc, nº 8.

75 IBIDEM.

76 Cfr. A.H.N. Sección Nobleza.Osuna.C.1664. D-2. Vid. Apéndice Documental. Doc, nº 8.

77 IBIDEM.
} 


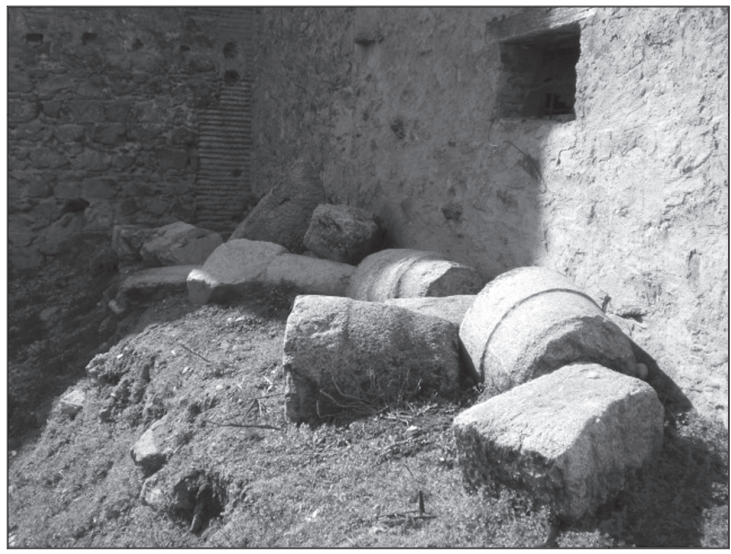

Ilustración 8. Restos de columnas del corredor. Alcázar Buitrago.

de cantería labrada decorada con claraboyas góticas "en cada lumbre la suya"78 y su propio pasamanos "llanos conforme a los que su señoría tiene en sus casas de Guadalajara con sus buenas molduras"79.

Sobre los aspectos propiamente decorativos sabemos que los arcos del corredor debían llevar en sus albánegas sendos escudos "con las armas de su señoría y de la señora duquesa" "E0. Éstos debían de ser idénticos a los de los arcos del patio del alcázar, excepto "que debían de ser de mayor cuerpo". Una vez más, observamos cierta pretensión por guardar unidad estilística en el conjunto, pues junto con las claraboyas, basas y capiteles, todo debía de ejecutarse conforme a lo ya existente. Del mismo modo, se especifica que los pasamanos del corredor debían de simular "a los que su señoría tiene en sus casas de Guadalajara" ${ }^{81}$ y suponemos que deben aludir a los del palacio guadalcarreño del Infantado, modelo o referente de la arquitectura civil castellana en estos momentos.

Junto a ello, se señala cómo "esta dicha obra sea de haser de piedra berroqueña la mejor que se pudiere aver tal que sea sufiçiente e muy buena la dicha piedra". Con esta denominación se llama a una piedra de naturaleza granítica, muy variable en función de su textura, color y composición, que pudo proceder de las cercanas canteras de la zona de Valdemanco o el Berrueco. Situados al norte de la Comunidad de Madrid, en las últimas estribaciones de la sierra de Guadarrama, entre dos alineamientos montañosos que los separan de las provincias de Guadalajara y Segovia, ambos municipios tuvieron una larga tradición en la extracción del granito ${ }^{82}$. De acuerdo con Fort González, esta zona pertenece a un plutón con dos diferentes tipos de granito, a saber: leucogranitos de grano fino-medio y con minerales característicos (cordierita) y monzogranito de grano biotítico y con anfíbol. Posiblemente, la propia cantería del corredor correspondería con este último tipo ${ }^{83}$.

En otro orden de cosas, el maestro Martín de Gamecho se comprometía a tener finalizada la obra en los inicios de noviembre de 1514 "al día de todos los Santos primo que verná", percibiendo

78 Cfr. A.H.N. Sección Nobleza. Osuna. C.1664. D-2. Vid. Apéndice Documental. Doc, nº 8.

79 IBIDEM.

80 Cfr. A.H.N. Sección Nobleza. Osuna. C.1554. D-2. Vid. Apéndice Documental. Doc. nº 8.

81 IBIDEM.

82 De hecho, el vocablo Berrueco, literalmente peñasco rocoso, parece deberse al cerro de granito que domina al núcleo de población por el norte.

83 Agradecemos al Dr. Rafael Fort González, del Instituto de Geología Económica (CSIC-UCM), este importante dato. Junto con el Instituto Geológico y Minero de España (Tres Cantos-Madrid) aborda estos aspectos de manera más amplia en el proyecto titulado: Caracterización tecnológica de las piedas de construcción empleadas en el patrimonio cultural de la Comunidad de Madrid. Sobre ello existen ya algunas publicaciones que pueden ser consultadas: Cfr. MENDUIÑA FERNÁNDEZ, Juan, FORT GONZÁLEZ, Rafael et alt: Las piedras utilizadas en la construcción de los bienes de interés cultural de la Comunidad de Madrid hasta el siglo XIX. Madrid,2005. Asimismo, FORT GONZÁLEZ, Rafael: "Localización de antiguas canteras utilizadas en el patrimonio monumental", en Degradación y conservación del Patrimonio Arquitectónico. Madrid, 1996, pp. 311-316. 
por ella 300.000 maravedíes, repartidos en esta guisa, a saber: 200.000 maravedíes por el corredor bajo y 100.000 maravedíes por el alto. Sin embargo, el contrato especificaba que "sy su señoría no quisyere hacer más del dicho corredor baxo", los honorarios serían abonados en tercios de maravedíes, o sea, 100.000 maravedíes al principio para hacer frente a la obra, 60.000 maravedíes a fines del mes de agosto y, por último, otro pago de 60.000 maravedíes ya finalizada la obra. Del mismo modo, "sy su señorýa quisiere que se haga el dicho corredor alto que todavía el dicho Martín de Gamecho sea obligado e se obligue de lo haser". Por ello, Gamecho recibiría los 100.000 maravedíes en tres pagos proporcionales, es decir, al inicio, mediada la obra y finalizada la misma.

Sea como fuere, es importante destacar cómo el corredor bajo se realizó dentro del plazo fijado en el contrato, quedando finalizado en noviembre de 1514. Por él, recibiría dos pagos, uno de 80.000 maravedíes, de manos del tesorero del duque Juan de Alcalá ${ }^{84}$, y otro de 120.000 maravedíes, de Francisco Díaz, regidor de la villa de $\operatorname{Prado}^{85}$. En este último caso, los dineros se libraban de ciertas rentas que la Casa Ducal tenía en los señoríos madrileños de Prado y Méntrida ${ }^{86}$, dos de las 800 villas y lugares que contribuían con sus rentas al monto total de 120.000 ducados que poseían los duques.

El corredor alto no corrió la misma suerte, pues su obra se demoró, no siendo acabado hasta 1521 , cuando Martín de Gamecho recibía un último pago de 10.000 maravedíes por finalizar sus claraboyas ${ }^{87}$. En cualquier caso, debe hacerse notar cómo entre 1515 y 1521, la documentación registra distintos pagos por las labores de cantería desarrolladas en el mismo. Estos dineros se obtenían de la recaudación de las rentas- tercias y martiniegas- de los señoríos de Buitrago, Hita, Prado, Méntrida y de la encomienda de Paracuellos ${ }^{88}$.

Sea como fuere, enero de 1521 es el último dato documental que conocemos sobre la actividad de Martín de Gamecho. Por el funcionamiento de la cantería de la época, resulta probable que el maestro, una vez finalizado el contrato adquirido con el III duque del Infantado, se viera implicado en otras labores, hasta el momento desconocidas.

\section{Apéndice Documental}

\section{DOCUMENTO 1}

1503. Marzo.27. Sin lugar.

Don Juan de la Cerda, duque de Medinaceli, y los testamentarios del duque don Luis, su padre y antecesor, ordenan a Pedro Tejada, receptor, que libre al mayordomo Juan Ortega 20.000 maravedíes para los trabajos que Martín de Gamecho, cantero, realiza en el campanario y tribuna de la iglesia de Santa María de Medinaceli.

A.D.M. Sección Archivo Histórico. Leg. 183, nº 3.

Yo don Juan de la Çerda duque de Medinaçely conde del Puerto de Santa Marýa señor de Huelva y / Deça y don Álvaro Carrillo de Albornoz y don Pedro de Castilla testamentarios que somos del / muy ylustre señor el señor don Luys de la Çerda duque de Medinaçely que santa gloria aya nuestro / señor mandamos a vos Pedro de Tejada nuestro recebtor que de qualesquier maravedís que vos están carga- $/$ dos en el año pasado de myll y quynientos e dos años y de los que en este presente año se vos / cargará dedes a Juan de Ortega mayordomo de la obra de la yglesia de Santa María de la / villa de Medina veynte myll maravedís los quales le mandamos dar para gastar en el canpa- / nario y trebuna de la dicha yglesia que se hase por nuestro mandado segúnd está conçertado / con Martýn de Gamecho cantero de que a de

\footnotetext{
84 Cfr. A.H.N. Sección Nobleza. Osuna. C.1664. D-2. Vid. Apéndice Documental. Doc. nº 9.

85 Cfr. A.H.N. Sección Nobleza. Osuna. C.1664. D-2. Vid. Apéndice Documental. Doc, nº 10.

86 Eran una herencia que don Diego Hurtado de Mendoza, III duque del Infantado, había recibido de su madre, doña María de Luna. Ésta al casar en 1460 con don Íñigo López de Mendoza, II duque del Infantado, llevo como dote Alamín, Berciana, Méntrida, la Torre, el Prado y otras muchas propiedades, confirmadas en los documentos de 1461 y en el llamado mayorazgo de Luna de 1484. Cfr. SÁNCHEZ PRIETO, Ana Belén: La Casa de Mendoza...; opus.cit. p. 299. vid. nota. 1079.

87 Cfr. A.H.N. Sección Nobleza. Osuna. C.1664. D-2. Vid. Apéndice Documental, Doc. nº 18.

88 Cfr. A.H.N. Sección Nobleza. Osuna, C.1664. D-2. Vid. Apéndice Documental. Doc, nº 11, 12, 13, 14, $15,16,17$ y 18.
} 
dar cuenta y rrazón y dadgelos y pagadgelos y to- / mad su carta de pago con la qual y con esta mandamos que vos sean rreçebidos y pasados en / cuenta los dichos veynte myll maravedís. Fecha a veynte y syete días del mes de março de myll y quinyentos y tres años. El duque (rúbrica). Alonso Carrillo de Albornoz (rúbrica).

\section{DOCUMENTO 2}

1503. Julio. 1. Sin lugar.

Don Juan de la Cerda, duque de Medinaceli, y los testamentarios del duque don Luis, su padre y antecesor, ordenan a Pedro Tejada, receptor, que libre al mayordomo Juan Ortega 50.000 maravedies para los trabajos que Martín de Gamecho, cantero, realiza en el campanario y tribuna de la iglesia de Santa María de Medinaceli.

A.D.M. Sección Archivo Histórico. Leg. 183, nº 3.

Yo don Juan de la Çerda duque de Medinaceli conde del Puerto de Santa María señor de / Huelva y de Deça y yo don Pedro de Castilla y don Álvaro Carrillo de Albornoz tes- / tamentarios que somos del muy ylustre señor el señor don Luys de la Çerda duque de / Medinaçely que santa gloria aya nuestro señor mandamos a vos Pedro de Tejada nuestro / rreçebtor que de qualesquier maravedís que aveys rreçebido por nuestro mandado y os an de ser / cargados este año de la fecha de esta carta de libramyento dedes a Juan de Ortega ma- / yordomo de la yglesia de Santa María de la vylla de Medina çinquenta myll maravedís los / quales le mandamos dar para gastar en el canpanario y trebuna de la dicha yglesia / que se hase por nuestro mandado segúnd está conçertado con Martýn de Gamecho cantero / de que ha de dar cuenta y rrazón y dadgelos y pagadgelos y tomad su carta de pago con la / qual y con esta mandamos que vos sean rreçebidos y pasados en cuenta los dichos çinquenta / myll maravedís. Fecha a primo dýa del mes de jullio de myll y quinyentos y tres años. El duque (rúbrica). Alonso Carrillo de Albornoz (rúbrica). Pedro de Castilla (rúbrica).

\section{DOCUMENTO 3}

1503. Septiembre. 3. Sin Lugar.

Don Juan de la Cerda, duque de Medinaceli, y los testamentarios del duque don Luis, su padre y antecesor, ordenan a Pedro Tejada, receptor, que libre al mayordomo Juan Ortega 15.000 maravedíes para los trabajos que Martín de Gamecho, cantero, realiza en el campanario y tribuna de la iglesia de Santa María de Medinaceli.

A.D.M. Sección Archivo Histórico. Leg. 183, nº 3.

Yo don Juan de la Çerda duque de Medinaçely conde del Puerto de Santa Marýa señor de Huelva y de Deça y don / Pedro de Castilla y don Álvaro Carrillo de Albornoz testamentarios que somos del muy ylustre señor / el señor don Luys de la Çerda duque de Medinaçely que santa gloria aya nuestro señor mandamos a vos / Pedro de Tejada nuestro rreçebtor que de qualesquier maravedís que por nuestro mandado aveys rreçebido y os an de / ser cargados este año de la fecha de esta carta de libramyento dedes a Juan de Ortega mayordomo de / la obra de la yglesia de Santa Marýaa de la villa de Medinaçely quinze myll maravedís los quales le mandamos / dar para gastar en el canpanario e trebuna que se haze por nuestro mandado en la dicha yglesia segúnd / está conçertado con Martýn de Gamecho cantero que ha de dar cuenta y razón y dadgelos y pagadge- / los y tomad su carta de pago con la qual y con esta mandamos que vos sean rreçebidos y pasados en / cuenta los dichos quinze myll maravedís. Fecha a treynta días del mes de setyenbre de myll e quinyen- / tos e tres años. El duque (rúbrica), Pedro de Castilla (rúbrica). 


\section{DOCUMENTO 4}

1503. Septiembre. 15. Sin Lugar.

Don Juan de la Cerda, duque de Medinaceli, y los testamentarios del duque don Luis, su padre y antecesor, ordenan a Pedro Tejada, receptor, que libre al mayordomo Juan Ortega 10.000 maravedies para que termine de pagar a Martín de Gamecho, cantero, los trabajos que realiza en el campanario y tribuna de la iglesia de Santa María de Medinaceli.

A.D.M. Sección Archivo Histórico. Leg. 183, nº.3.

Yo don Juan de la Çerda duque de Medinaçely conde del Puerto de Santa Marýa señor de Huelva y de Deça y don / Pedro de Castilla y don Álvaro Carrillo de Albornoz testamentarios que somos del muy ylustre señor / el señor don Luys de la Çerda duque de Medinaçely que santa gloria aya nuestro señor mandamos a vos Pe- / dro de Tejada nuestro rreçebtor que de los maravedís que por nuestro mandado aveys rreçebido y os an der carga- / dos en el año pasado de myll y quinyentos y tres años dedes a Juan de Ortega mayordomo de la / obra de la yglesia de Santa Marýa de la villa de Medinaçely diez myll maravedís los quales le manda-/ mos dar para acabar de pagar a Martýn de Gamecho cantero el canpanario y trebuna que hizo / por nuestro mandado en la dicha yglesia de Santa Marýa que fue ygualado en doszientos y quinze myll / maravedís segúnd se contiene en la obligaçión y contrataçión que sobre ello pasó ante escriuano de que a de / dar cuenta y rrazón y dadgelos y pagadgelos y tomad su carta de pago con la qual y con esta mandamos / que vos sean rreçebidos y pasados en cuenta los dichos diez myll maravedís. Fecha a quinze días del mes / de setyenbre de myll y quinyentos y tres años. El duque (rúbrica). Pedro de Castilla (rúbrica).

\section{DOCUMENTO 5}

1503. Noviembre.16. Sin lugar.

Don Juan de la Cerda, duque de Medinaceli, y los testamentarios del duque don Luis, su padre y antecesor, ordenan a Pedro Tejada, receptor, que libre al mayordomo Juan Ortega 10.000 maravedíes para los trabajos que Martín de Gamecho, cantero, realiza en el campanario y tribuna de la iglesia de Santa María de Medinaceli.

A.D.M. Sección Archivo Histórico. Leg. 183, nº. 3.

Yo don Juan de la Çerda duque de Medinaçely conde del Puerto de Santa Marýa señor de Huelva / y de Deça y don Pedro de Castilla y don Álvaro Carrillo de Albornoz testamentarios que somos del muy ylustre señor el señor don Luys de la Çerda duque de Medinaçely que santa gloria aya / nuestro señor mandamos a vos Pedro de Tejada nuestro rreçebtor que de qualesquier maravedís que por nuestro / mandado aveys rreçebido y os an de ser cargados este año de la fecha desta carta de libramyento / dedes a Juan de Ortega mayordomo de la obra de la obra de la yglesia de Santa Marýa de la villa de / Medina diez myll maravedís los quales le mandamos dar para gastar en el canpabario y tre- / buna que se haze por nuestro mandado en la dicha yglesia segúnd está asentado con Martýn / de Gamecho cantero de que a de dar cuenta y razón y dadgelos y pagadgelos y tomad / su carta de pago con la qual y con esta mando que vos sean rreçebidos y pasados en cuenta los / dichos diez myll maravedís. Fecha a diez y seys días del mes de novyenbre de myll e quinyentos y tres / años. El duque (rúbrica). Pedro de Castilla (rúbrica).

\section{DOCUMENTO 6}

1504. Abril. 3. Sin Lugar.

Don Juan de la Cerda, duque de Medinaceli, y los testamentarios del duque don Luis, su padre y antecesor, ordenan a Pedro Tejada, receptor, que libre al mayordomo Juan Ortega 10.000 maravedíes para los trabajos que Martín de Gamecho, cantero, realiza en el campanario y tribuna de la iglesia de Santa María de Medinaceli.

A.D.M. Archivo Histórico. Leg. 183, nº 3. 
Yo don Juan de la Çerda duque de Medinaçely conde del Puerto de Santa Marýa señor de Huelva y de / Deça y don Pedro de Castilla y don Álvaro Carrillo de Albornoz testamentarios que somos / del muy ylustre señor el señor don Luys de la Çerda duque de Medinaçely que santa gloria / aya nuestro señor mandamos a vos Pedro de Tejada nuestro rreçebtor que de qualesquier maravedís que por / nuestro mandado aveys rreçebido y os an de ser cargados en el año pasado de myll y qunyentos / y tres años dedes a Juan de Ortega mayordomo de la obra de la yglesia de Santa Marýa de la / villa de Medinaçely diez myll maravedís los quales le mandamos dar para gastar en el canpanario / y trebuna que se haze por nuestro mandado en la dicha yglesia segúnd está asentado con Martýn / de Gamecho cantero de que a de dar cuenta y rrazón y dadgelos y pagadgelos y tomad su carta de / pago con la qual y con esta mandamos que vos sean rreçebidos y pasados en cuenta los dichos / diez myll maravedís. Fecha a tres días del mes de abril de myll e quinyentos y quatro años. El duque (rúbrica). Álvaro Carrillo de Albornoz (rúbrica). Pedro de Castilla (rúbrica).

\section{DOCUMENTO 7}

1504. Septiembre. 15. Sin lugar.

Don Juan de la Cerda, duque de Medinaceli, y los testamentarios del duque don Luis, su padre y antecesor, ordenan a Pedro de Tejada, receptor, que libre al mayordomo Juan de Ortega 3.675 maravedies para pagar las demasías de los trabajos que Martín de Gamecho, cantero, había hecho en la tribuna y campanario de la iglesia de Santa María de Medinaceli, según la tasación realizada por los canteros Francisco de Medina, Ortuño de Garnica y García de Liébana.

A.D.M. Sección Archivo Histórico. Leg. 183, nº 3.

Yo don Juan de la Çerda duque de Medinaçely conde del Puerto de Santa Marýa señor de Huelva y de / de [sic] Deça y don Pedro de Castilla y don Álvaro Carrillo de Albornoz testamentarios que somos del muy ylustre / señor el señor don Luys de la Çerda duque de Medinaçely que santa gloria aya nuestro señor mandamos / a vos Pedro de Tejada nuestro rreçebtor que de los maravedís que por nuestro mandado aveys rreçebido y os an / de ser cargados en el año pasado de myll y quinyentos y tres años dedes a Juan de Ortega ma- / yordomo de la obra de la yglesia de Santa Marýa de la dicha villa de Medinaçely tres myll seisçientos / y setenta y çinco myll maravedís los quales mandamos dar para pagarlos a Martýn de Gamecho, cante- / ro, las demasías que hizo de más de lo que era obligado en el canpanario e y trebuna que hizo / por nuestro mandado en la dicha yglesia segúnd se contiene en la tasaçión que se hizo por Francisco de / Medina y por Ortuño de Garnyca y por García de Liébana que a de dar cuenta y rrazón y dad- / gelos y pagadgelos y tomad su carta de pago con la qual y con esta mandamos que vos sean / rreçebidos y pasados en cuenta los dichos tres myll y seisçeintos y setenta y çinco. Fecha / quinze días del mes de setyenbre de myll y quinyentos y quatro años.

\section{DOCUMENTO 8}

1514, mayo, 20. Buitrago.

Condiciones con las que Martín de Gamecho, maestro de cantería, se compromete a hacer un corredor para el Castillo-alcázar del duque del Infantado en la villa de Buitrago.

A.H.N. Sección Nobleza.Osuna.C.1664. D-2.

Corredor alto y baxo del alcaçar de Buytrago. Obligaçión que hiso Martýn de Gamecho.

(calderón) En la villa de Buytrago veynte días del mes de mayo año del nasçimyento de nuestro señor / Ihesucristo de myll e quinientos e catorse años este día se obligó Martýn de Ga- / mecho maestro de cantería e vesyno de la çibdad de Guadalajara al ylustrísimo e muy / magnífico señor el señor duque del Infantadgo de haser un corredor alto de / y baxo en el alcáçar de la dicha vylla de Buytrago a la parte del río de forma syguida.

(calderón) Primamente a de llevarme dicho corredor çinquenta / tapias de pared de cal y canto y más sy más / fueren menester hasta venyr en rasón y se asyen- / ten ocho arcos y sy su señoría quisyere 
que sean / nueve y sea obligado a los haser. Sobre estas dichas / tapias sean de asentar las basas de los pilares de / dicho corredor, esta pared a de ser de çinco pies de / grueso bien çimentado sobre la prima biva / esto del ancho que su señoría mandare que sea el dicho corredor / y su dicha pared a de ser dende torre a torre todo / lo que monta el terrado alto de largo a largo y sobre / esta dicha pared de cal y canto sean de haser ocho arcos a lo / largo repartidos y el dicho largo a cada uno lo que le / cupiere y a los lados sean de haser dos arcos los / quales no an de llevar pilares junto con la pared.

(calderón) Ytem.Que los dichos arcos y pilares an de ser de tamaño / e grueso dellos a de ser y lleven cada uno tres pies / de grueso de medida que es una vara y an de llevar / sus basas y capiteles conforme a los que están hechos / en el patio de la casa del dicho alcáçar, an de ser redondos / y los dichos arcos que an de venir sobre éstos an de ser de / medio punto y si le pareçiere a su señoría que suban más /haser sean de otro punto que sea más sólido porque sea / más sygura la obra y ansý cerrados estos arcos / an de venyr sobre ellos la syllería que fuere menester / con sus cabeçaduras y ansý hechados estos syllares / los que fueren menester an de llevar su entablamen- / to ençima conforme a lo que fuere menester de manera / que suba este primer suelo pilares y arcos y syllería / y entablamento al alto de la dicha sala que sale al río. / An de llevar los lados a los cabos desta dicha / dança de arcos sus botaretes de / syllería con sus esquynas byvas / tan grandes como fueren me- / nester para estribo de los arcos y lleve / seys pies e medio de votarete y quatro pies y medio / de grueso. Esta dicha obra sea de haser de pie- / dra berroqueña la mejor que se pudiere aver tal que sea su- / fiçiente e muy buena la dicha piedra.

(calderón)Y hecho esto sean de elegir luego sobre estos / otros tantos arcos como los baxos conforme / a ellos de alto y grueso que fueren menester / con que lleven su syllería y entablamento y sus caños por donde corra el agua esto a de / ser de piedra blanca que sea muy buena de la piedra / que están hechas las claraboyas de los corredores / del dicho alcáçar.

(calderón) Item. Estos dichos pilares sean de haser sus / claraboyas en cada lumbre la suya las quales / an de ser conforme a las que agora están hechas / en los dichos corredores del dicho alcáçar y los pasama- / nos dellas an de ser ser [sic] llanos conforme / a los que su señoría tiene en sus casas de Guadalajara con sus bue/ nas molduras.

(calderón) Otrosý. Sy por caso su señoría acordare que quede este / dicho corredor primero en el piso de dicha sala que los / pilares sean enteros con el entablamento / y rrespondan a los lados por donde corre el / dicho entablamento lo más largo que ser pudi- / ere porque las varandas estén más fuertes.

(calderón) Ase de poner en cada arco un escudo con las ar- / mas de su señoría y de la señora duquesa conforme / a los que están en los arcos del patio salvo que an / de ser de mayor cuerpo.

(calderón) Que si su señoría acordare que quede este corredor en el / primer suelo que se ayan de haser sus carriles / por donde salga el agua.

(calderón) A de quedar toda esta dicha obra muy bien rre- / vocada a vista de ofiçiales y a contentamyento de su señoría.

La qual dicha obra en la forma susodicha el dicho Martýn de Gamecho se obligó / de dar hecha y acabada de aquý al día de todos Santos primo que verná de / este dicho presente año de myll e quinientos e catorze años a toda su costa / perfectamente a vista de maestros y de ofiçiales según dicho es sopena / que su señoría pueda tomar a su costa maestros que hagan la dicha obra con / que su señoría le aya de mandar y pagar por toda la dicha obra tresçientas myll / maravedís en dineros contados en esta manera por el dicho corredor baxo las dosyentas myll / maravedís y por el dicho corredor alto los çien myll maravedís con que sy su señoría no quisyere / haser más del dicho corredor baxo que se le ayan de pagar las dichas dosyentas myll maravedís / pagados en esta manera los ochenta myll maravedís dellos luego antes que comyençen la dicha / obra e los sesenta myll maravedís en fin del mes de agosto deste dicho presente año / e los que sesenta myll maravedís por el dicho día de todos santos luego siguiente y a de / ser acabada la dicha obra y si su señoría quisyere que se haga el dicho corredor alto que toda- / vía el dicho Martýn de Gamecho sea obligado e se obligue de lo haser según dicho es por los / dichos çien myll maravedís los quales su señoría les aya de mandar dar y pagar en esta mane-/ra la terçia parte luego como comiençe la dicha obra y la otra terçia parte como / oviere fecho la mytad de la dicha obra e luego la otra terçia parte acabada la dicha / obra que sea acabando de pagar dello para lo qual el dicho Martýn de Gamecho se obligó / de lo ansý haser en tener e cumplir e haser la dicha obra por el dicho preçio de las dichas / tresyentas myll maravedís en la forma susodicha sopena de çinquenta myll / maravedís para el dicho señor duque si no cumpliere la 
dicha obra a los plasos y de la manera / que dicha es e dio poder a las justiçias para que por todo rrigor de derecho le apre-/ myen e costringan a lo asý hazer e conplir para que ejecuten en él la dicha / pena si en ella yncurriere e renunció todas las leyes e fueros e derechos de / que se pudiese ayudar e aprovechar para yr o venir contra lo en esta carta contenido y le non / vala e todas ferias de pan e vino y el traslado desta carta y el dicho señor / duque se obligó de dar y pagar al dicho Martýn de Gamecho las dichas tresyentas / myll maravedíes por la dicha obra a los dichos plasos y de la forma e manera que dicha es e obligó / a ello sus bienes e dio poder a las justiçias para que ansý guelo hagan cumplir / e pagar de lo qual a más las dichas partes otorgaron dos escrituras de un tenor / tal la una como la otra para cada una de las suyas e firmaron en este rre- / gistro sus nombres para que cada una parte que paresçiere ansý en juysio como fuera del / haganse bien ansý a tan complidamente como sy a más a dos paresçieren. Testigos / que fueron presentes a todo los susodicho. Diego Suárez Dávila firmó [veedor] obras de su señoría porque el dicho Gamecho en este registro firmó. (rúbricas).Diego de Esquivel por maestro de la çibdad de Guadalajara no sabía firmar e firmó Orejón por él. Por testigo Orejón (rúbrica).

\section{DOCUMENTO 9}

1514 , mayo, 20. Buitrago.

El duque del Infantado ordena a Juan de Alcalá, su tesorero, que libre en Martín de Gamecho, maestro cantero, 80.000 maravedies en concepto de las obras que hace en el corredor del castillo de Buitrago. A.H.N. Sección Nobleza. Osuna. C.1664. D-2.

Libranças para esta obra por mandado de su señoría de esta guisa. El thesorero Juan de Alcalá. Corredor de Buitrago. LXXX U maravedís.

(calderón) Juan de Alcalá mi tesorero yo vos mando que de los / maravedís de vuestro cargo que os he mandado o mandare / librar este presente año de myll e quinientos e cartorze / años dedes a Martýn de Gamecho veçino de Guadalajara o a / quien su por derecho [quisiere] LXXX U maravedís que los a de / aver por quenta de las CC U maravedís que yo le / ove de dar para la obra del corredor de / sobre el rrío que él se obligó de haser / de piedra berroqueña en el alçázar de la my vylla / de Buitrago según se contiene en la obligaçión que / dello otorgó Antón Alonso Gutiérrez de Escalona que está asen- / tada en mys libros e dadgelos luego e to- / mad su carta de pago o de quien en el dicho su poder oviere / con la qual e con esta mando que vos sean rreçebidos e pasados / en quenta los dichos LXXX U maravedís. Fecha en la mi villa de Buitrago a / XX días del mes de mayo año de DXIIII años. El / duque del Ynfantado. Alonso de Çañizares.

\section{DOCUMENTO 10}

1514, mayo, 20. Sin lugar.

El duque del Infantado ordena a Francisco Díaz, regidor de la villa de Prado, que de los maravedies obtenidos de la venta de ciertas rentas de las villas de Prado y Méntrida, libre en Martín de Gamecho, maestro cantero, 120.000 maravedies en concepto de las obras que hace en el corredor del castillo de Buitrago.

A.H.N. Sección Nobleza. Osuna. C.1664. D-2.

Por mandado de su señoría de esta guisa. Françisco Díaz. El Prado. Corredor de Buitrago. CXX U maravedís.

(calderón) Françisco Díaz mi rregidor en la my villa del Prado yo / vos mando que de los maravedís de vuestro cargo de pan e / ganado que vos tuvistes cargo de cobrar en las mis villas / del Prado e Méntrida que vos las vendieres por / my mandado los años pasados de DXI DXII DXIII / años dedes a Martýn de Gamecho maestro de / cantería veçino de la çibdad de Guadalajara o a quien en su po- / der oviere CXX U mararavedís que las a de aver para compli- / myento de pago de las CC U que yo le ove de dar por la / obra del corredor de piedra que él se obligó de haser / en el alcáçar de la mi vylla de Buitrago según se con- / tiene en la obligaçión que dello otorgó Antón Alonso Gutiérrez de / Escalona 
escriuano que está asentada en los mis libros e dad- / gelos en fin del mes de agosto deste presente año de / quinientos e catorze años e tomad su carta de pago o de / quien en el dicho su poder oviere con la qual e con esta vos mando que vos / sean rreçebidos e pasados en quenta los dichos CXX U maravedís. Fecho a XX días de / mayo de DXIIII años. El duque del Ynfantado. Alonso de Cañizares.

(calderón) Conosco yo Martýn de Gamecho que llevo en my poder estas dos libranças / de su señoría de contýa de CC U maravedís para las cobrar en las personas que van libradas / las quales son para lo que tengo de aver por el corredor baxo de piedra que yo hago / en el alcáçar de Buitrago. E porque no sabía firmar rogué Martín Sanz deVesvua que lo firmase por mí. Martín Sanz de Vesvua (rúbrica).

\section{DOCUMENTO 11}

1515, junio, 13. Sin lugar.

Varias libranzas del duque del Infantado a Martín de Gamecho por las obras que hace en el corredor del alcázar de Buitrago.

A.H.N. Sección Nobleza. Osuna. C.1664. D-2.

Librança para los C U del corredor alto de la fortaleza de Buytrago

(regidor de Buytrago, pan vendido) (calderón) Que se libraron al dicho Martýn de Gamecho por carta / del duque mi señor fecha a XIII días del mes de / junio de DXV años X maravedís en Alonso Gutierrez del Rayo / rreceptor de Buytrago en los maravedís del pan que vendió / del pan de su cargo e rrentas de las terçias / e martyniegas de la villa de Buitrago e / su tierra del año pasado de quynientos e / treze años (X U)

(Hernando Cal de Rondavila)(restánse de aquýporque están en otras ojas deste pliego)(calderón) Que se libraron más al dicho Martýn de Gamecho / por otra carta del duque my señor fecha a trese de / junio de DXV años en Hernando Cal de Ronda-/vyla mayordomo de la hasyenda de la señora duquesa / receptor en los maravedís de su cargo deste año de / quinientos e quinse años $(X X U)$

Libranza para los C U del corredor alto de la fortaleza de Buytrago

(calderón)(rreceptor de Buiytrago pan vendido) Que se libraron al dicho Martýn de Gamecho por / carta del duque my señor fecha a XIII días del / mes de junio de DXV años en Alonso Gutiérrez / del rayo rreceptor de Buytrago en los maravedís del pan que / vendió del pan de su cargo e rrentas / de las terçias e martiniegas de la vylla de Buytrago e su tierra del año / pasado de DX DXIIII años ( $X U$ )

(Hernando Cal de Rondavyla) (calderón) Que se libraron más al dicho Martýn de Ga- / mecho por carta del duque my señor fecha a trese / de junio de DXV años XX U en Hernando Cal de Ron/davyla mayordomo de la hasyenda de la / señora duquesa del Infantado en los maravedís de su cargo deste / año de DXV años $(X X U)$

Conozco yo Martýn de Gamecho que rrecibý del señor / contador los dos libramientos de suso contenidos para en parte de pago de los cien / myll maravedís que tengo de aver para el corredor de / Buytrago e porque no sabía firmar rogué a Juan Ál- / varez que lo firmase por mi. A ruego del dicho Martýn de Gamecho lo firmé por testigo. Juan Álvarez (rúbrica).

\section{DOCUMENTO 12}

1515, julio, 27. Sin lugar.

Don Rodrigo de Mendoza manda librar a Juan de Céspedes, alcaide de Paracuellos, 40.000 maravedies, provenientes de la renta del pan, en Martín de Gamecho.

A.H.N. Sección Nobleza. Osuna. C.1664. D-2. 
(Paracuellos)(calderón) Que se libraron más al dicho Martýn de Gamecho por carta del señor / don Rodrigo de Mendoça fecha a XXVII de jullio de XV años / quarenta myll maravedís en Juan Çéspedes alcayde de Paracuellos / en los maravedís de su cargo de la encomyenda de Paracuellos de los años pasados / de DXIII DXIIII años en el pan vendido del dicho año de DXIIII. Por testigo. Gallego (rúbrica) $(X L U)$

\section{DOCUMENTO 13}

1516, febrero, 25. Sin lugar.

El duque del Infantado manda librar a los receptores de Buitrago, Alonso Gutiérrez del Rayo y Hernando de Sosa, 30.000 maravedies, provenientes de las tercias y martiniegas de la renta del pan, en Martín de Gamecho,

A.H.N. Sección Nobleza. Osuna. C.1664. D-2.

(Buitrago) (calderón) Que se libraron más al dicho Martýn de Gamecho / por dos cartas de libramyentos firmadas del duque my señor / fechas a XXV de hebrero de DXVI años XXX U desta guisa / los XV U en Alonso Gutiérrez del Rayo rreçeptor que fue de Buytrago / el año pasado de DXIIII años en el pan de su cargo / de las terçias e martiniegas del dicho año y los otros XVU / en Hernando de Sosa rreçeptor de la dicha vylla de Buytrago / de los maravedís de su cargo del pan de las dichas terçias / e martiniegas del año pasado de DXV años pasa- / dos luego. Por testigo Gallego (rúbrica) XXX.

\section{DOCUMENTO 14}

1516, junio, 25. Guadalajara.

Obligación de Martín de Gamecho para acabar el corredor alto del alcázar de Buitrago.

A.H.N. Sección Nobleza. Osuna. C.1664. D-2.

En la çibdad de Guadalajara myércoles veynte e çinco días del / mes de junio año del señor de myll e quinyentos e diez e seys años / este dicho día Martýn de Gamecho veçino de la dicha çibdad dixo que por quanto él estava / obligado de faser la obra en este contrato contenyda a térmyno que él contrató dentro del / qual fixo el corredor baxo e el alto no se pudo acabar porque su señoría lo mandó faser lo / más rrico e se hubo de buscar nueva cantería para lo faser e por no lo aver fecho / su señoría mandava pedirle so la pena e despusuvo con él que lo acabase de aquý al día de / San Myguel deste presente año por ende que a mandado [...] / e contrato a contrato que él se obliga e obligase a acabar el / dicho corredor alto de aquý al día de San Miguel próximo deste dicho año suplica / que su señoría no sea obligado a le pagar cosa alguna de la demasýa de lo / que valieron más de lo que vale como se había de faser e que su señoría lo pueda / mandar a acabar a costa del dicho Martýn de Gamecho e de sus bienes para lo qual asý / thener e guardar e cumplir e pagar e manthener de la forma e manera en derecho obligó su / persona e bienes muebles e raíces avidos e por aver e dio por su fiador / de mancomún e a bos de uno a cada uno por el todo a Luys de Gutiérrez veçino de la / Çelada que presente estava e ambos a dos se obligaron a todo lo susodicho para lo / el dicho Martýn de Gamecho como principal debdor e el dicho Luis de Gutiérrez como su / fiador e principal pagador obligaron sus personas e todos sus bienes muebles e raices / avydos e por aver e dieron poder cumplido a todas e qualesquier justiçia e juezes / que sean antes quienes esta carta paresçiere e dello fuese pedido cumplimiento de / justiçia para que por todo rremedio de derecho e esecuçión e los constringan / asýmismo a lo asý thener e guardar e cumplir e pagar como sy por sentençia / definitiva de juez competente asý fuesen juzgados e sentençiados sobre lo qual / dixeron que renunçiavan e renunçiaron a toda qualesquier leyes e fueros e derechos / e todas ferias de pan e vino coger e el traslado desta carta e espeçialmente / renunçiaron la ley que dis que general renunçiación fecha que non vala e porque / sea válido e firme firmaron con sus nombre el rregistro esta e en la fecha / susodicha testigos que fueron presentes a lo que dicho es Antón Gutiérrez de Sal e el bachiller Rodrigo Díaz e Alonso de Rojas veçinos de Guadalajara. Luis Gutiérrez (rúbrica).Por testigo Alonso de Rojas (rúbrica). Pasó ante my Françisco de Torres (rúbrica). 


\section{DOCUMENTO 15}

1520, julio, 16. Sin lugar.

El duque del Infantado manda librar a Francisco de Madrid, receptor de la villa de Hita, 12.000 maravedies, provenientes de las rentas, en Martín de Gamecho.

A.H.N. Sección Nobleza. Osuna. C.1664. D-2.

(calderón) (Hita) Que se libraron al dicho Martýn de Gamecho por carta del duque my señor fecha a / XVI de julio de DXX años XII U maravedís para acabar de faser la dicha / obra en Françisco de Madrid receptor de la villa de Hita en los/ maravedís de su cargo e renta del año pasado de DXIX / años con todo pan vendido.

\section{DOCUMENTO 16}

1520, julio,18. Guadalajara.

Martín de Gamecho, cantero, y Juan de Oro, su fiador, se obligan a acabar la obra del corredor de Buitrago por precio de 12.000 maravedíes.

A.H.N. Sección Nobleza. Osuna. C.1664. D-2.

Corredor alto e baxo de Buytrago

Sepan quantos esta carta de obligaçión / vieren como en la çibdad de Guadalajara / diez e ocho días del mes de julio de / quynientos e veynte años este dicho Martýn de Gamecho / cantero e veçino de Guadalajara como principal debdor e Juan / de Oro veçino de Guadalajara como su fiador e principal pagador / e ambos a dos de mancomún renunçiando las leyes / de la [mancomunydad e duobus rrex de vendi y el abtentica presente ${ }^{89}$ desymos que por quanto / el ylustrísimo señor el señor duque del Infantado me libra en el dicho / Gamecho en Françisco de Madrid rreceptor de Hita del año pasado / de quinyentos e diez e nueve años dose myll maravedís / para acabar de faser la dicha obra de los corredores / de la fortalesa de Buytrago por ende que se obligan / e obligaron de dadgeselos los dichos dose myll / maravedís en la dicha obra de aquý a San Myguel de setiembre primero / que verná demás e allende de lo que le está librado / e gastado en ella de los libramyentos contados su señoría / para lo qual obligaron sus personas e bienes mueble e raízez avydos / e por aver e renunçiaron leyes e ferias e dieron poder / a las justiçias que asý se lo fagan cumplir e pagar como / sy por sentençia difinitiva de juez competente asý fuese / juzgado e otorgaron esta carta de obligaçión en la / forma susodicha. Testigos que fueron presentes Fernado de Sesa veçino de Buitrago e Diego Cortés e Diego de Sastre veçinos de Guadalajara. E porque el dicho Martýn de Gamecho dixo que no sabía / firmar rogó al dicho Sastre que lo firmase por él por testigo.(rúbricas)

\section{DOCUMENTO 17}

1521, enero, 18. Sin lugar.

Libranza a favor de Martín de Gamecho de 10.000 maravedies.

A.H.N. Sección Nobleza. Osuna. C.1664. D-2.

(calderón) Que se libraron más al dicho Martýn de Gamecho por otra carta del duque mi señor fecha a XVIII de henero de DXXI años otros X U en Diego López Sea predicador e veçino de Guadalajara en los XXX U que le fueron librados en Fernando Calderón [tinta desvaída] Este libramiento de los X U no ovo efecto en los rrecibos de Gamecho porque dellos dio Diego López Sea veçino de Guadalajara. Diego López quenta segund paresçió por vale.

Libraronse a los herederos de Gamecho con estos maravedís

\footnotetext{
89 En el texto aparece de forma muy abreviada.
} 


\section{DOCUMENTO 18}

1521, enero, 19.Guadalajara.

Martín de Gamecho,cantero, y Juan de Oro, su fiador, se obligan a acabar las claraboyas del corredor de Buitrago por 10.000 maravedies.

A.H.N. Sección Nobleza. Osuna. C.1664. D-2.

(calderón) En Guadalajara diez e nueve de enero de quinientos e / veynte e un año otorgaron carta / de obligaçión e fiança / los dichos Martýn de Gamecho / e Juan de Oro en la forma / a su obligaçión y por otros / diez myll maravedís que el dicho señor / duque libró al dicho Martýn / de Gamecho para acabar / las claraboyas del / corredor de Buytrago en / Diego López Sea veçino de Guadalajara / obligaron sus personas / e bienes renunçiaron / leyes e ferias dieron poder / a las justiçias otorgaron carta / de obligaçión. Testigos / Alonso de Vallejo e Diego Cortés / veçinos de Guadalajara. Por mý e por el dicho Martýn de / Gamecho. Juan de Oro (rúbrica). Pasó ante mí Alonso Gutiérrez (rúbrica). 